\title{
Early Paleogene planktic foraminifera in thin-sections - an experiment on isolated specimens from the Fore-Magura Thrust Sheet (Polish Outer Carpathians)
}

\author{
Weronika BALINIAK ${ }^{1}$ and Ewa MALATA ${ }^{1, *}$
}

1 Institute of Geological Sciences, Jagiellonian University, Gronostajowa 3a, 30-387 Kraków, Poland

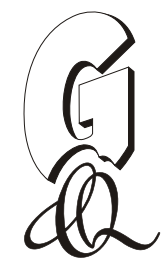

\begin{abstract}
Baliniak, W., Malata, E., 2017. Early Paleogene planktic foraminifera in thin-sections - an experiment on isolated specimens from the Fore-Magura Thrust Sheet (Polish Outer Carpathians). Geological Quarterly, 61 (3): 655-681, doi: $10.7306 / \mathrm{gq} .1363$

This paper describes results of an experiment aimed mainly at obtaining random thin-sections of isolated specimens of planktic foraminifera determined to a species level. Twenty species of uppermost Paleocene-Middle Eocene planktic foraminifera from pelagic variegated marls of the Fore-Magura Thrust Sheet have been chosen for this experiment. These planktic foraminifera belong to the genera Chiloguembelina, Turborotalia, Acarinina, Morozovella, Muricoglobigerina, Subbotina and Parasubbotina. Their SEM images, stereomicroscope photos of isolated specimens, and the experimental thin-sections along with their systematics and stratigraphic ranges are presented.
\end{abstract}

Key words: Paleocene-Middle Eocene planktic foraminifera, random thin-sections, experiment on isolated specimens, Fore-Magura Thrust Sheet.

INTRODUCTION

The study of planktic foraminifera in thin-sections is sometimes the only possible tool to date lithified pelagic sediments. In case of single rock samples of unknown provenance, it can be a very difficult task, particularly when cross-sections of microfossils are rare and accidental. This problem gave rise to an idea of preparing random sections across numerous and well-determined isolated specimens of planktic foraminifera that can be used in thin-section analyses of sedimentary rocks. The research required very rich assemblages of planktic foraminfera. Such assemblages were found in the Fore-Magura Unit deposits of the Polish Outer Carpathians (POC; Malata, 2013).

The Fore-Magura Unit (see Burtan and Sokołowski, 1956; Ksią kiewicz, 1972), or the Fore-Magura Thust Sheet (F-MTS) according to elaźniewicz et al. (2011), occurs in a narrow belt in front of the Magura Nappe in the western part of the POC (Fig. 1). Its deposits display some facies affinities to both the Magura Basin expressed by the Upper Cretaceous flysch-type Biotite Beds, and the Silesian sedimentary domain indicated by the similar deposits of the uppermost Eocene and Oligocene (Fig. 2). The characteristic and distinguishing feature of the F-MTS is the presence of the Upper Cretaceous-Eocene deep-water pelagic marls.

\footnotetext{
* Corresponding author, e-mail: ewa.malata@uj.edu.pl Received: January 31, 2017; accepted: April 11, 2017; first published online: June 1, 2017
}

\section{MATERIAL AND METHODS}

For the purpose of this work, 15 samples abundant in planktic foraminifera were chosen from five sections of Paleocene-Eocene marls of the F-MTS, SW of ywiec (Fig. 1). The most numerous specimens of particular genera were selected from each of these 15 assemblages and then determined to a species level. Each taxon identified must have been represented by a considerable amount of specimens (at least 10 but usually 30-40). Those specimens, which best fitted to the descriptions of particular species, were photographed in reflected light using a Sony A330 digital camera mounted on a Nikon SMZ 1500 stereomicroscope. Then, scanning microphotographs were also taken using a Hitachi S-4700 Scanning Microscope. Approximately 500 specimens of planktic foraminifera were examined in our experiment.

After completing the photographic documentation of the specimens, thin-sections were prepared according to our experimental procedure. Several specimens of particular species were randomly put on the standard microscopic glass slide and then immersed in epoxy resin (Araldyte 1000-Struers). Such a preparation was dried for a few hours at a temperature of $\sim 50^{\circ} \mathrm{C}$ in the lab oven until it was completely hardened. In the next step, the slides were hand-ground using consecutively 1500 , 2500 and 4000 abrasive papers, down to the thickness appropriate for the observations in the transmitted light microscope (Nikon ECLIPSE 50I). Finally, they were mechanically polished to eliminate abrasive grooves. More than twenty microscopic slides were prepared in this way. Each of these slides consists of several cross-sections of particular species, displaying various and random orientations of specimens. 


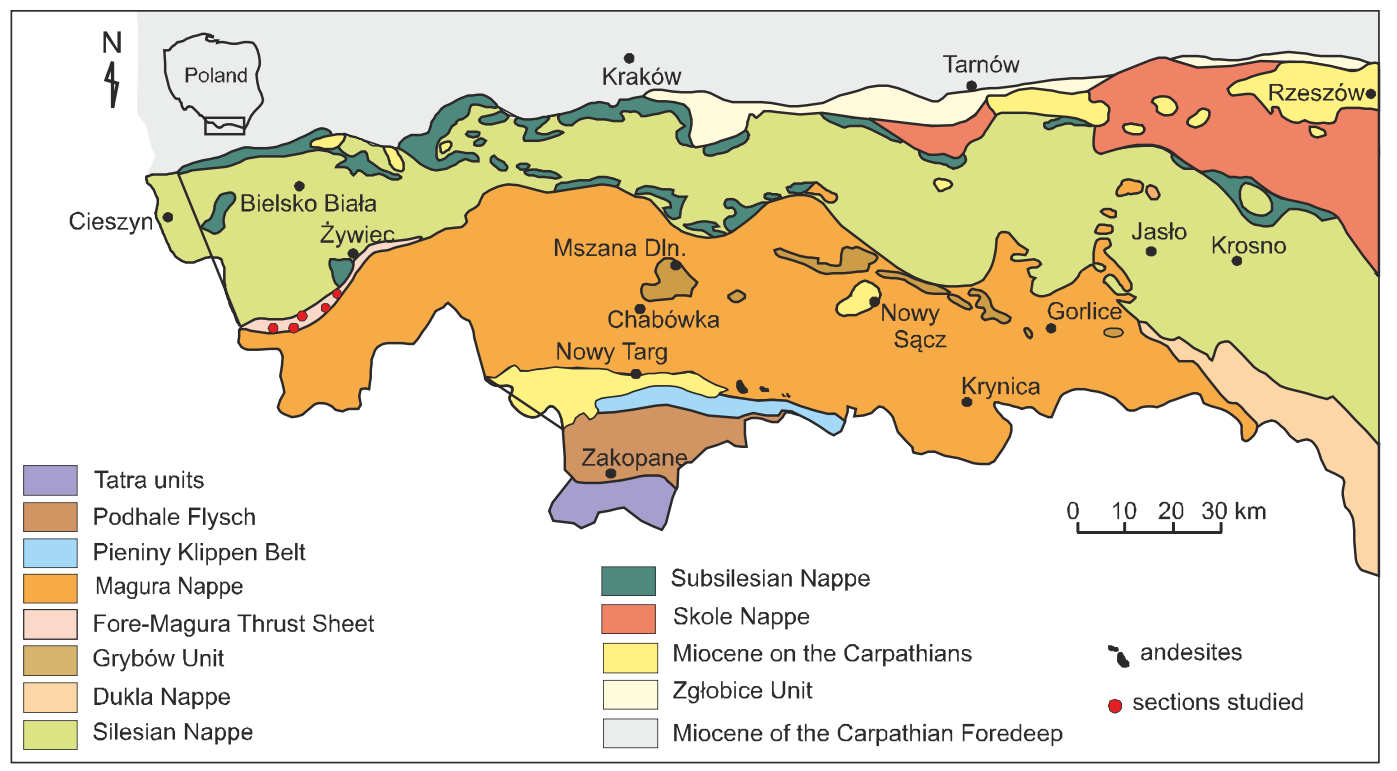

Fig. 1. Tectonic sketch-map of the western part of the Polish Outer Carpathians with the position of sections studied in the Fore-Magura Thrust Sheet (after Malata et al., 1996; Lexa et al., 2000, supplemented)

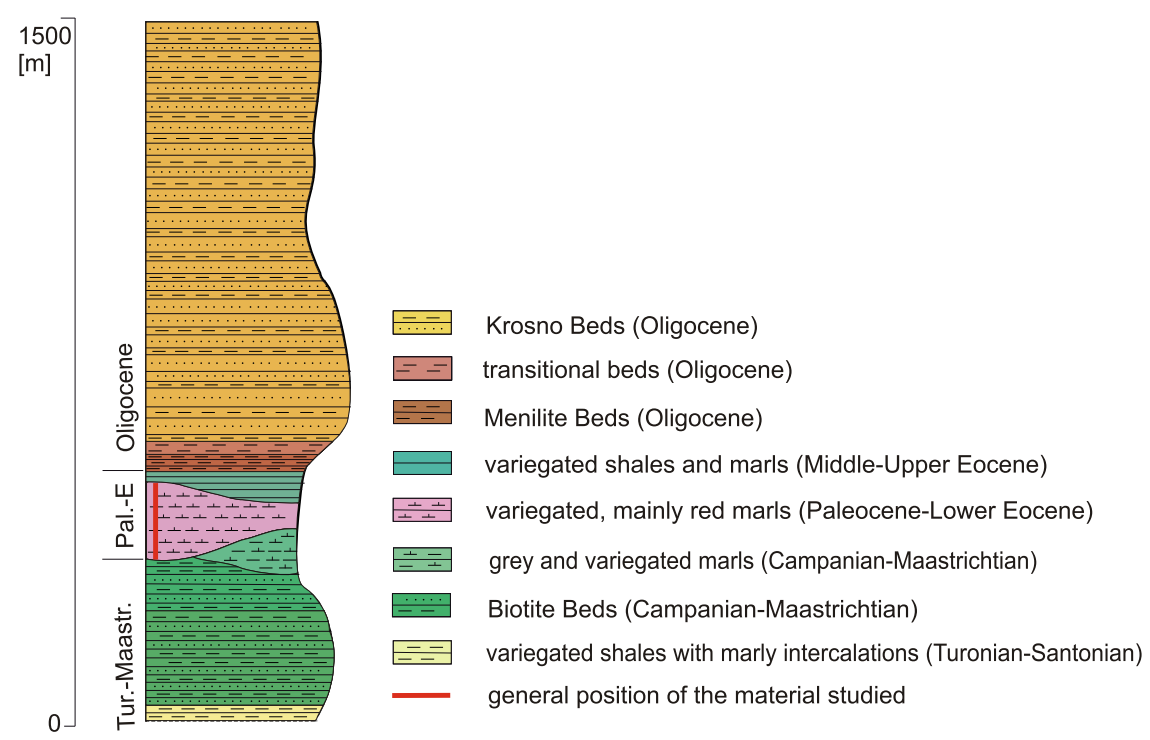

Fig. 2. Stratigraphic log of the Fore-Magura Thrust Sheet (northern zone according to Burtan and Sokołowski, 1956)

The selected planktic species represent two types of morphologies - multichambered biserial and multichambered trochospiral. The latter consists of genera displaying different shapes, i.e. Acarinina and Morozovella types as well as Subbotina type, including forms with globular chambers and more or less spherical tests. Drawings and names of different sections, used in the text, are presented in Figure 3.

\section{PRESENTATION OF RESULTS}

Following the pattern of pioneering work of Postuma (1971) and Premoli Silva et al. (2003), twenty species of planktic foraminifera are presented in the form of scanning microscope images, stereoscope microscope photographs of isolated specimens, and several best cross-sections, chosen from the experimental slides prepared for each species (Figs. 4-23).

\section{SYSTEMATICS AND REMARKS}

ON EXPERIMENTAL THIN-SECTIONS

Chiloguembelina trinitatensis

(Cushman and Renz, 1942)

(Fig. 4) 


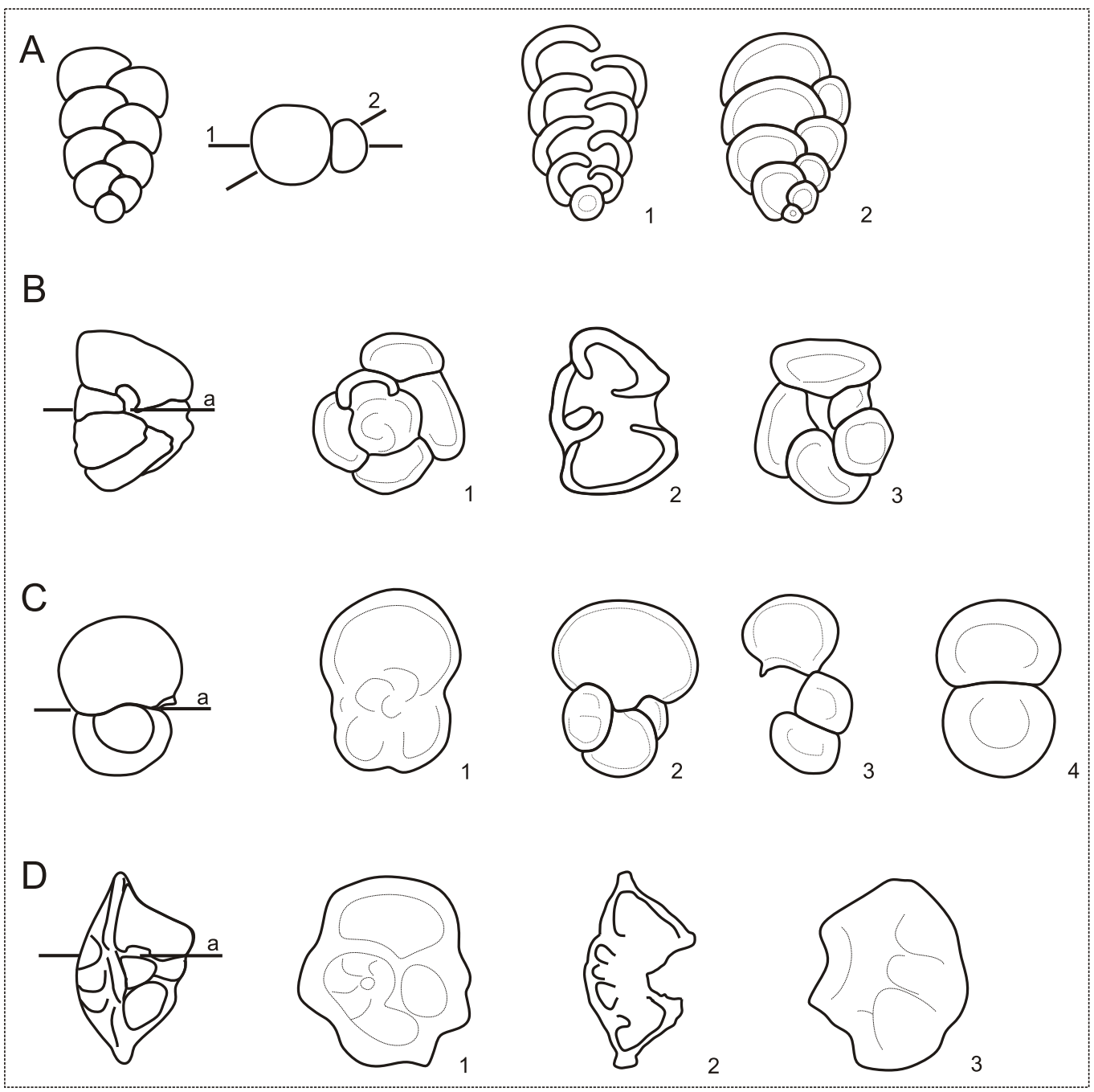

Fig. 3. Glossary to experimental sections through biserial and trochospiral morphology of foraminiferal growth (A - after Flügel, 2004)

A - biserial: 1 - axial sagittal, 2 - axial oblique; $\mathbf{B}$ - trochospiral (Acarinina type): 1 -transversal dorsal, 2 - axial, 3 -transversal oblique; $\mathbf{C}$ - trochospiral (Subbotina type): 1 - transversal ventral or dorsal, 2 -axial, 3 - relict axial, 4 -transversal oblique; D - trochospiral (Morozovella type): 1 - transversal ventral or dorsal, 2-axial, 3 - transversal oblique; a - axis of chamber coil

Gümbelina trinitatensis n. sp. - Cushman and Renz (1942): 4, pl. 2 , figs. $8 a, b$.

Chilogumebelina trinitatensis (Cushman and Renz) - D'Hondt and Huber (1999): 92, pl. 13, figs. 11, 16; pl. 70, figs. 8-10.

Chiloguembelina trinitatensis (Cushman and Renz) - Huber et al. (2006): 475, 476, pl. 16.2, figs. 1-5.

St r a tig raphic rang e. - Latest Paleocene-Early Eocene (P5-E3 zones; Berggren and Pearson, 2005; Pearson et al., 2006).

$\mathrm{R}$ e $\mathrm{marks}$. - One of the characteristic features of this species is an arch-like aperture with a lip, symmetrically centered such as shown in Figure 4D. The characteristic features of the species are visible in most of the sections. In Figure 4I, almost all chambers are preserved in the section, but in the others, the initial parts of tests are missing. Figure $4 \mathrm{~K}-\mathrm{M}$ represents cuts that are axially shifted towards the edge of tests. Species identification can be based on the sections in Figure 4F, I.
Chiloguembelina wilcoxensis (Cushman and Ponton, 1932)

(Fig. 5)

Gümbelina wilcoxensis n. sp. - Cushman and Ponton (1932): 63, PI. 8 , fig. 17.

Chiloguembelina wilcoxensis (Cushman end Ponton) - Olszewska et al. (1996): 105, pl. 35, fig. 5.

Stratigraphic range. - Late Paleocene-Early Eocene (P4b-E4 zones; Berggren and Pearson, 2005; Pearson et al., 2006); in the POC, reported from the late Early Eocene (Olszewska et al., 1996).

R e m a rks. - Figure 5A, B, D, E shows the apertures covered by small, additional chambers of slightly irregular shape. In Figure 5G, J, L, the elements of the additional chamber covering apertures are preserved. Figure $5 \mathrm{~F}, \mathrm{~N}$ represents juvenile specimens. 


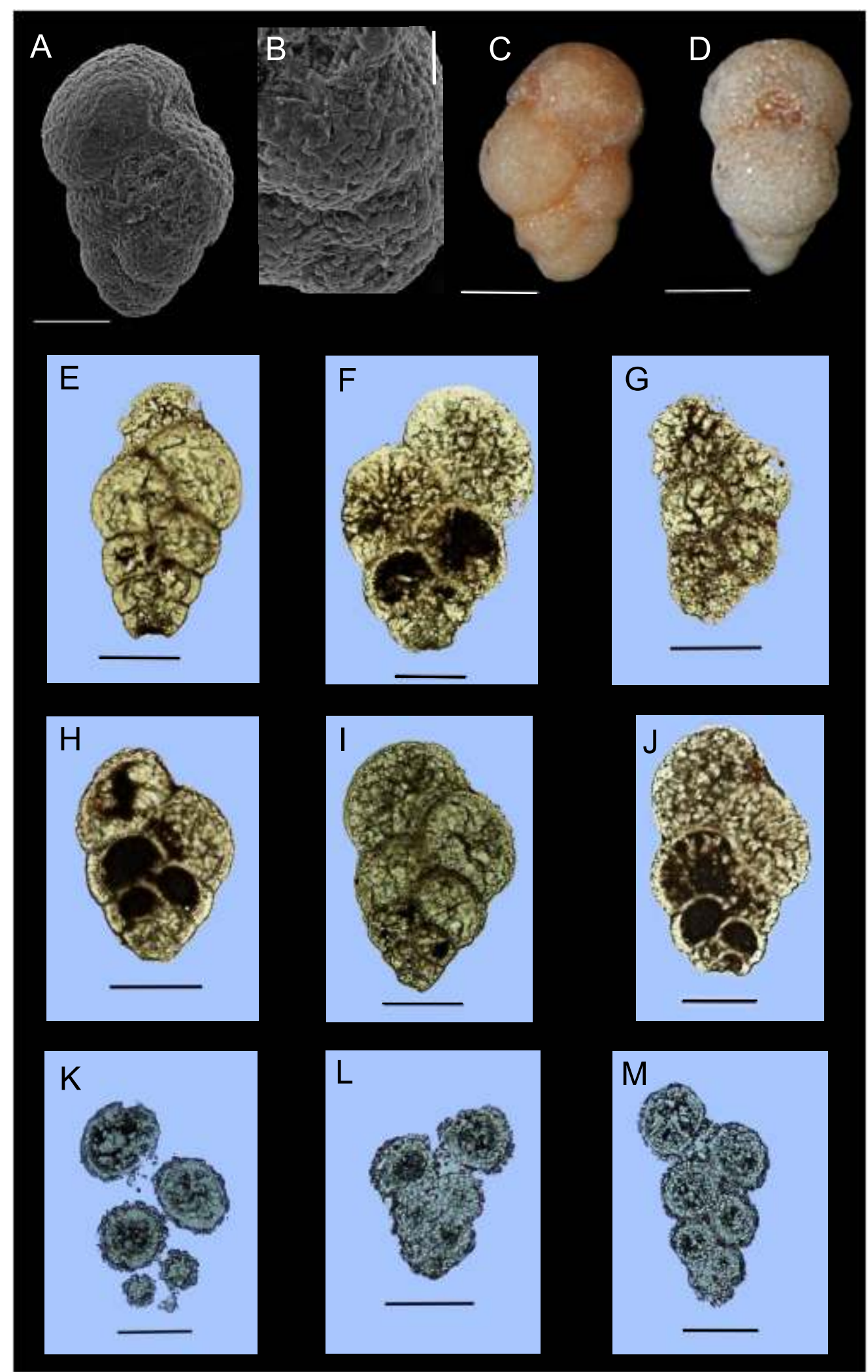

Fig. 4. Chiloguembelina trinitatensis (Cushman and Renz)

A - SEM image of isolated specimen; $\mathbf{B}$ - detail of surface of test A (scale bar $=25 \mu \mathrm{m}$ ); C, D stereomicroscope photos of isolated specimens; $\mathbf{E}-\mathbf{M}$ - transmitted light photos of experimental thin-sections of Ch. trinitatensis; scale bars $=100 \mu \mathrm{m}$ 

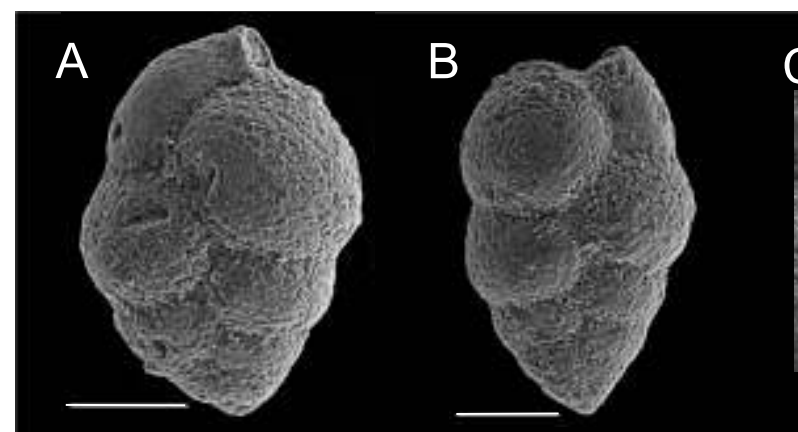

E
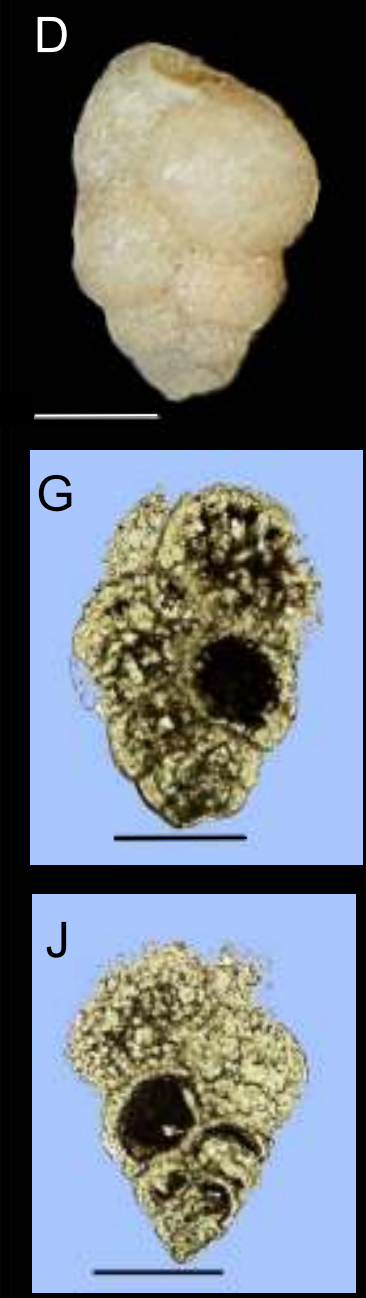

M
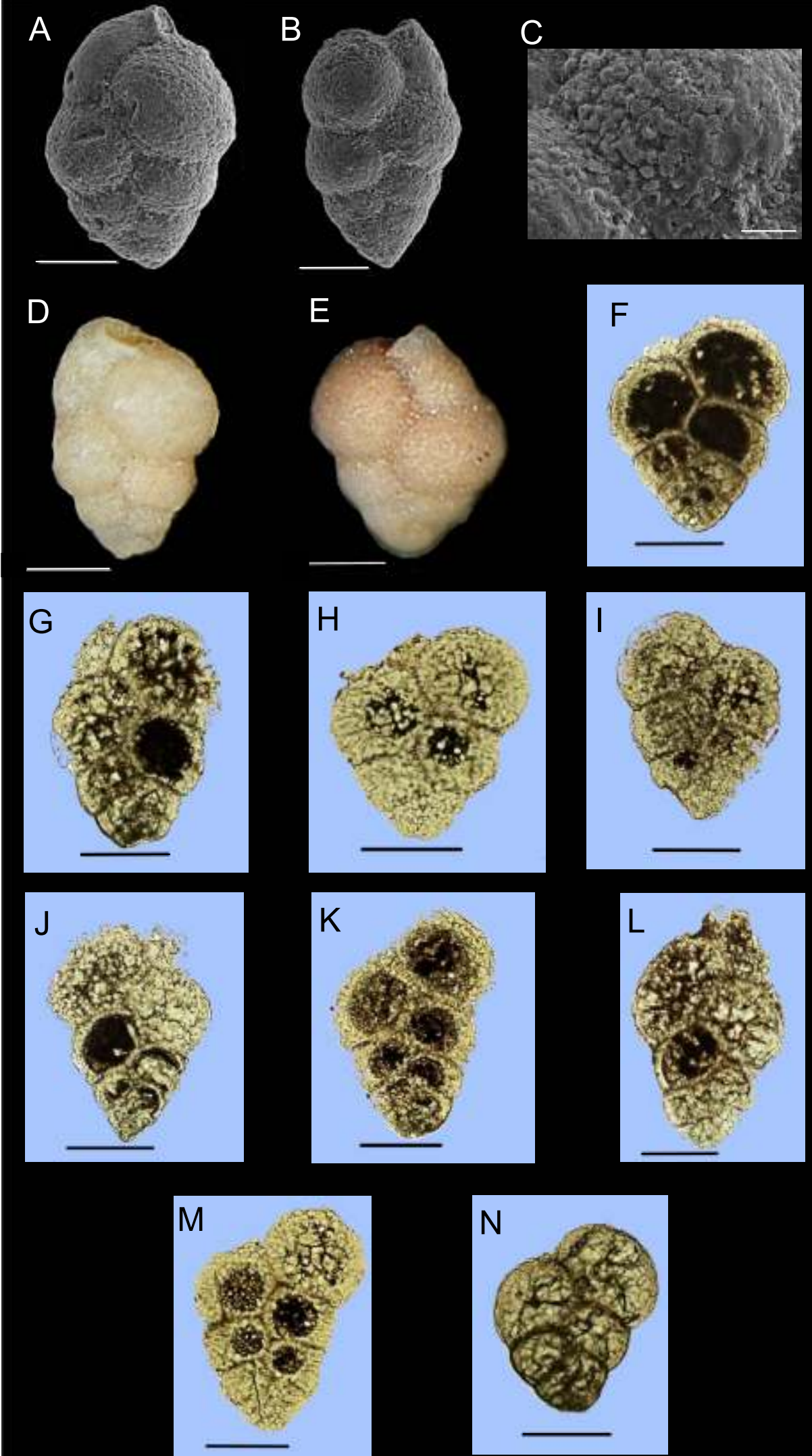

Fig. 5. Chiloguembelina wilcoxensis (Cuchman and Ponton)

A, B - SEM images of isolated specimens; C - detail of surface of test B (scale bar $=25 \mu \mathrm{m}$ ); D, E - stereomicroscope photos of isolated specimens; $\mathbf{F}-\mathbf{N}$ - transmitted light photos of experimental thin-sections of $\mathrm{Ch}$. wilcoxensis; scale bars $=100 \mu \mathrm{m}$ 
Species identification can be based on the sections in Figure $5 F, G, H$

The sections of both species of Chiloguembelina show great similarity, but chambers of $\mathrm{Ch}$. wilcoxensis seem to increase more rapidly and the traces of this small additional aperture-covering chamber are usually preserved in most of its axial cuts.

\section{Turborotalia frontosa (Subbotina, 1953)}

$$
\text { (Fig. 6) }
$$

Globigerina frontosa n. sp. - Subbotina (1953): 84, pl. 12, fig. 3. Turborotalia frontosa (Subbotina) - Olszewska et al. (1996): 112, pl. 40, figs. 13, 14.

Stratigraphic range. - Late Early-Middle Eocene (E7-E11 zones; Berggren and Pearson, 2005; Pearson et al., 2006); in the POC: Middle-early Late Eocene (Olszewska et al., 1996).

$\mathrm{R}$ e $\mathrm{m}$ a r k s. - This species is relatively easy to identify due to its general shape, number of chambers, and a characteristic extraumbilical aperture with a distinct lip (Fig. 6B, D), but the randomly-oriented sections do not reveal diagnostic features of the species. In Figure 6G, H, remnants of aperture lips are visible; in Figure $6 \mathrm{H}, \mathrm{I}$, the sections exhibit the test surface texture presented in a SEM image (Fig. 6C).

\section{Acarinina bullbrooki (Bolli, 1957) (Fig. 7)}

Globorotalia bullbrooki n. sp. - Bolli (1957): 167, pl. 38, fig. 5. Acarinina bullbrooki (Bolli) - Olszewska et al., 1996: 113, 114, pl. 36, figs. 10, 11 .

Acarinina bullbrooki (Bolli) - Berggren et al. (2006): 269, 271, 272, 275 , 276, pl. 9.6, figs. $1-16$.

S t r a t i g r a p h i c r a n g e. - Latest Early-early Middle Eocene (E7-E11 zones; Berggren and Pearson, 2005; Pearson et al., 2006); in the POC: latest Early Eocene-Middle Eocene (Olszewska et al., 1996).

$\mathrm{R} \mathrm{e} \mathrm{m}$ a r k s. - The concept of this species has been applied in our study according to Berggren et al. (2006). Obtained cuts (Fig. $7 \mid-K$ ) are more or less transversal to the axis of chamber coil. Figure $7 \mathrm{~J}$ and $\mathrm{H}$ shows the transverse dorsal (Fig. 3) and Figure I transverse ventral sections (see also Flügel, 2004: fig. 10.23). Figure $7 \mathrm{~L}$ represents axial cutting, transversal or "meridional" in relation to trochospiral coil, displaying the flat spiral side and the final chamber convexity at the umbilical side. Figure 7M shows only remnants of the test without any characteristic features. Species identification can be based on the sections in Figure $7 \mathrm{H}, \mathrm{J}$.

\section{Acarinina cf. esnaensis (LeRoy, 1953) (Fig. 8)}

Globigerina esnaensis n. sp. - LeRoy (1953): 31, pl. 6, figs. 8-10 (fide Ellis et Messina, Cat. of Foram.).

Acarinina esnaensis (LeRoy) - Berggren et al. (2006): 286-289, pl. 9.11, figs. $1-12$.

Stratigraphic range. - Late Paleocene-Early Eocene (P4b-E5 zones; Berggren and Pearson, 2005; Pearson et al., 2006).

R e m a rks. - The general shape of specimens corresponds to the description of the species and the picture of the holotype in Berggren et al. (2006). The characteristic texture of the test surface is not visible due to diagenetic obliteration. Figure $8 \mathrm{G}, \mathrm{I}, \mathrm{K}, \mathrm{M}$ and $\mathrm{O}$ presents transverse dorsal sections, while the others are oblique. In general, the thin-sections display the shape and morphology of isolated specimens. Species identification can be based on the sections in Figure 8G, M, O.

\section{Acarinina pentacamerata (Subbotina, 1947)}

(Fig. 9)

Globorotalia pentacamerata n. sp. - Subbotina (1947): 128, pl. 7, figs. 15-17 (fide Ellis et Messina, Cat. of Foram.).

Acarinina pentacamerata (Subbotina) - Berggren et al. (2006): 296, 297, pl. 9.15, figs. 1-16.

S t r a t i g r a p h i c r a n g e. - Late Early Eocene (E5-E7 zones; Berggren and Pearson, 2005; Pearson et al., 2006).

$\mathrm{R}$ e $\mathrm{m}$ a r k s. - Most of the experimental sections point to the random position of the specimens, transversal to the trochospiral axis, resulting in more or less oblique cuttings. Figure 9l shows 52 chambers of the last coil on the spiral side; this is the most complete section. In Figure 9L, K, the test surface texture is visible even in the incomplete "residual" section. Species identification can be based on the section in Figure 9l.

Morozovella aragonensis (Nuttal, 1930)

(Fig. 10)

Globorotalia aragonensis n. sp. - Nuttal (1930): 288, pl. 24, figs. 6-8, 10, 11 (fide Ellis et Messina, Cat. of. Foram.).

Morozovella aragonensis (Nuttal) - Olszewska et al. (1996): 118, 119, pl. 38 , figs. $17,18$.

Stratigraphic range. - Early-Middle Eocene (E5-E9 zones; Berggren and Pearson, 2005; Pearson et al., 2006); in the POC - late Early-Middle Eocene (Olszewska et al., 1996).

$\mathrm{R}$ e $\mathrm{m}$ a r k s. - Most of the experimental sections display incomplete "residual character" with no diagnostic features of the species. Figure $10 \mathrm{H}$ shows an axial section of the conical, trochospiral test, and the sections in Figure 10I, J, L most probably reveal remnants of the spiral sides.

Morozovella cf. caucasica (Glaessner, 1937)

(Fig. 11)

Globorotalia aragonensis Nuttall var. caucasica-Glaessner, 1937:31, 48, pl. 1, fig. 6a-c (fide Ellis et Messina, Cat. of Foram.).

Morozovella caucasica (Glaessner) - Berggren and Pearson, 2006: 354-358, pl. 11.4, figs. 1-16.

Stratigraphi c rang e. - Late Early-earliest Middle Eocene (E6-E8 zones; Berggren and Pearson, 2005; Pearson et al., 2006).

$\mathrm{R}$ e $\mathrm{m}$ a r k s. - The protruding part of the last chamber on the umbilical side is a characteristic feature of the species. Most of the sections display random cuts but more or less transverse to the axis of trochospiral coil. Figure $11 \mathrm{H}, \mathrm{K}$, R shows transversal sections of the flattened spiral side; Figure $11 \mathrm{H}, \mathrm{R}$ displays a thick marginal keel. Figure $11 \mathrm{~N}$ shows an axial section with the distinctly high last chamber. Species identification can be based on the sections in Figure $11 \mathrm{H}, \mathrm{K}, \mathrm{R}$.

\section{Morozovella gracilis (Bolli, 1957)}

$$
\text { (Fig. 12) }
$$

Globorotalia formosa ssp. gracilis - Bolli (1957): 75, pl. 18, figs. 4-6 (fide Ellis et Messina, Cat. of. Foram.).

Morozovella gracilis (Bolli) - Berggren et al. (1999): 61, 62, pl. 54, figs. 13-15.

Morozovella gracilis (Bolli) - Berggren and Pearson (2006): 366, pl.11.8, figs. 1-16. 


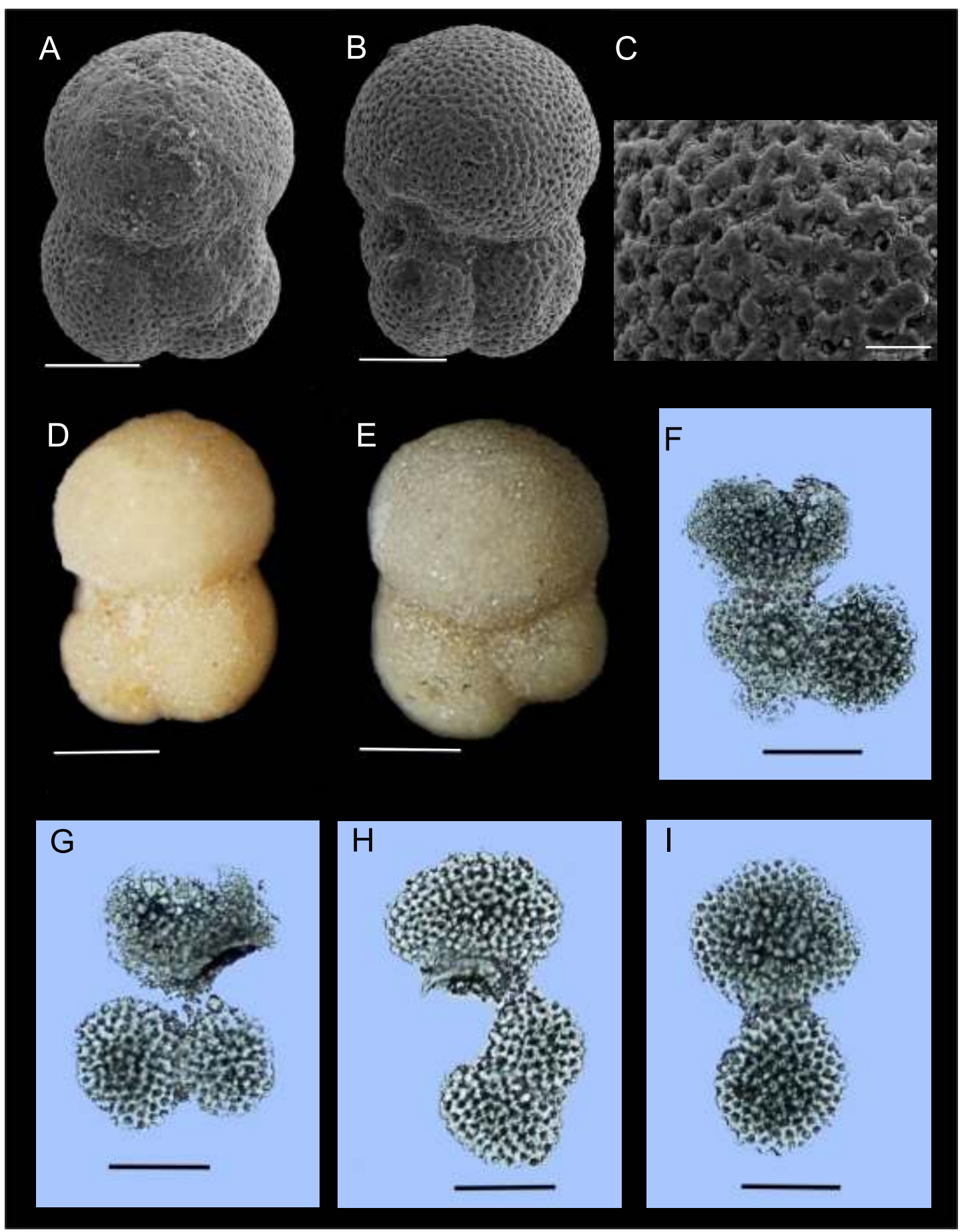

Fig. 6. Turborotalia frontosa (Subbotina)

A, B - SEM images of isolated specimens; C - detail of surface of test B (scale bar $=25 \mu \mathrm{m}$ ); D, E - stereomicroscope photos of isolated specimens; F-I - transmitted light photos of experimental thin-sections of $T$. frontosa; scale bars $=100 \mu \mathrm{m}$

Stratigraphic range. - Late Paleocene-Early Eocene (top P5-E5 zones; Berggren and Pearson, 2005; Pearson et al., 2006); in the POC - late Early Eocene (Olszewska et al., 1996).

$\mathrm{R}$ e $\mathrm{m}$ a rks. - The sections display all the chambers of the last coil on the umbilical side and the marginal keel. Figure $12 \mathrm{G}$ and $\mathrm{H}$ shows slightly oblique axial sections. Figure $12 \mathrm{~N}$ illustrates transverse dorsal cut. In Figure $12 \mathrm{G}$ and I, the specimens are obliquely cut, but all the chambers of the last coil are visible due to the convexity of the older (inner) coils. Species identification can be based on the sections in Figure 12G, M.

Morozovella lensiformis (Subbotina, 1953)

$$
\text { (Fig. 13) }
$$

Globorotalia lensiformis n. sp. - Subbotina, 1953: 214, pl. 18, fig. 4, 5. Morozovella lensiformis (Subbotina) - Olszewska et al., 1996: 119, pl. 37, figs. 15, 16. 


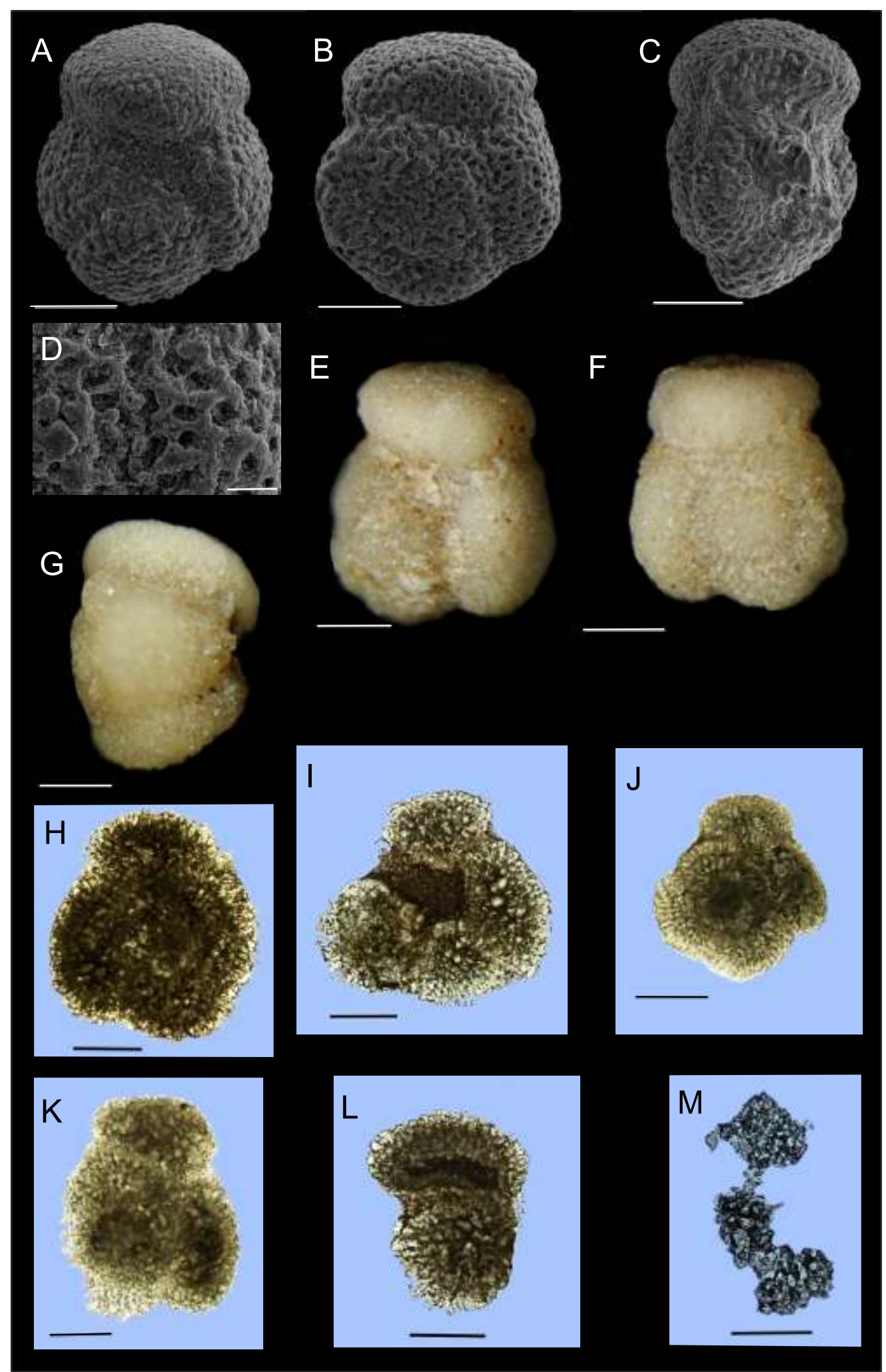

Fig. 7. Acarinina bullbrooki (Bolli)

A-C - SEM images of isolated specimens; D - detail of surface of test B (scale bar $=25 \mu \mathrm{m}$ ); $\mathbf{E}-\mathbf{G}$ - stereomicroscope photos of isolated specimens; $\mathbf{H}-\mathbf{M}$ - transmitted light photos of experimental thin-sections of $A$. bullbrooki; scale bars $=100 \mu \mathrm{m}$ 

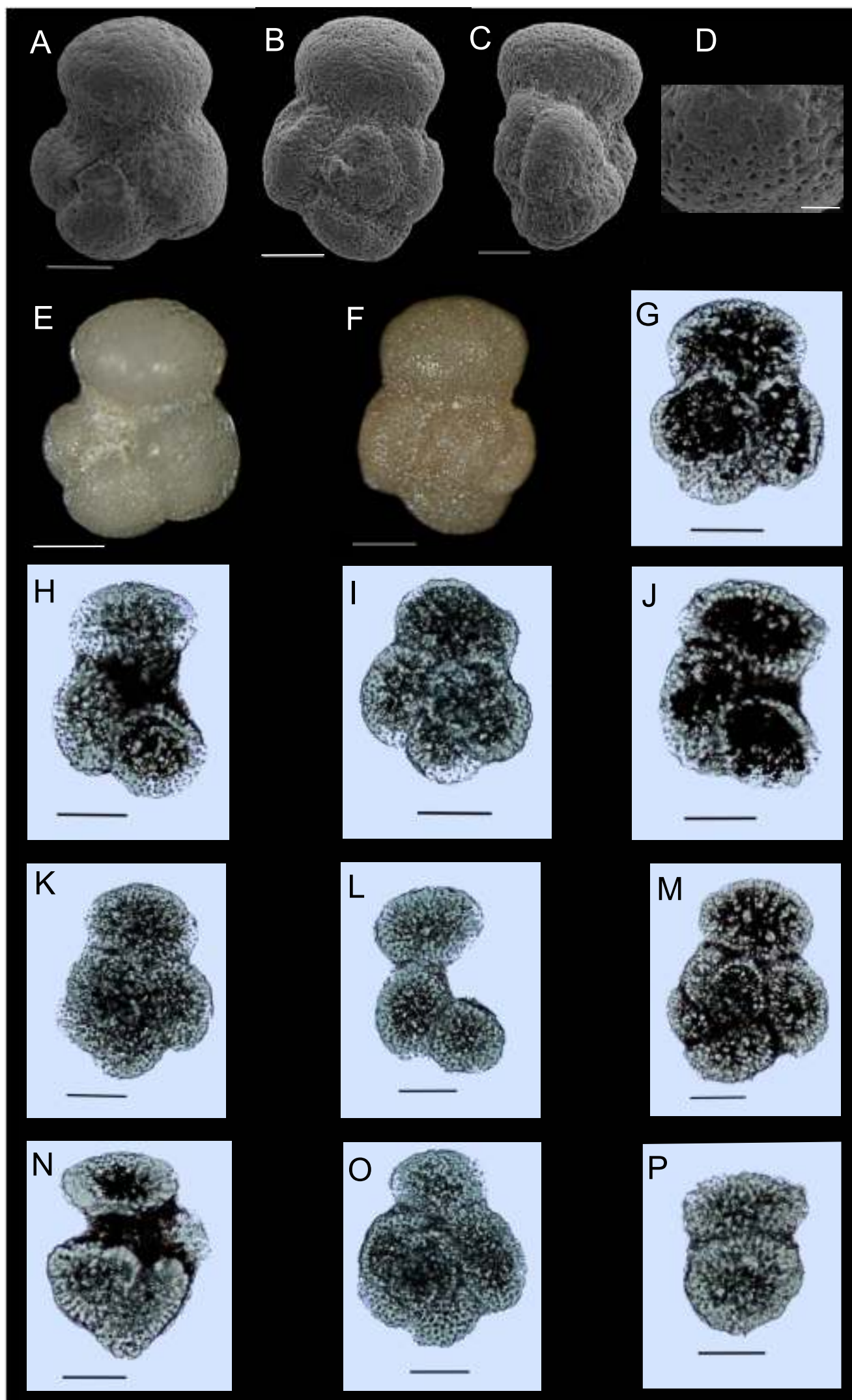

Fig. 8. Acarinina cf. esnaensis (LeRoy)

A-C - SEM images of isolated specimens; $\mathbf{D}$ - detail of surface of test $\mathbf{A}$ (scale bar $=25 \mu \mathrm{m}$ ); $\mathbf{E}, \mathbf{F}$ - stereomicroscope photos of isolated specimens; G-P - transmitted light photos of experimental thin-sections of $A$. cf. esnaensis; scale bars $=100 \mu \mathrm{m}$ 

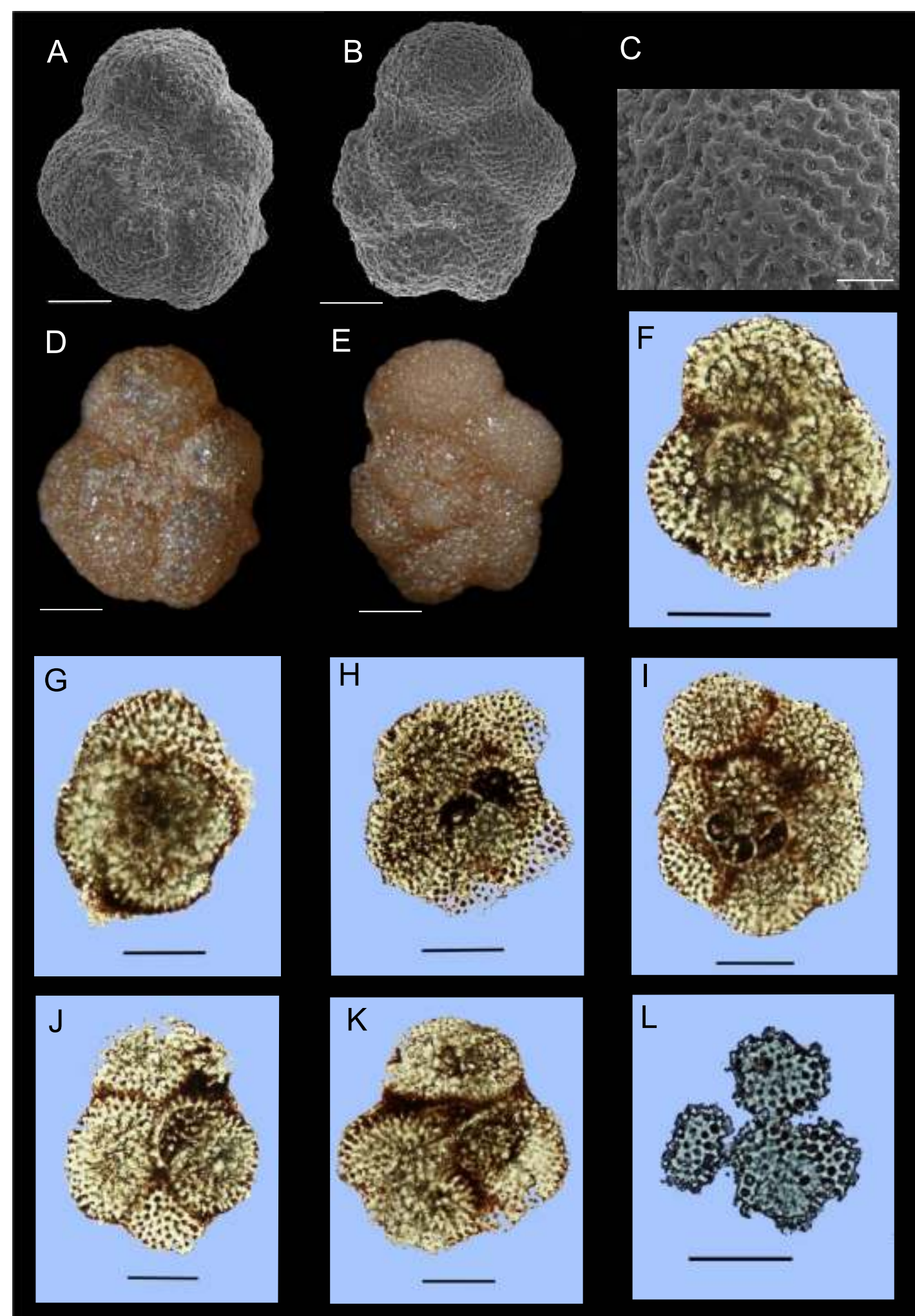

Fig. 9. Acarinina pentacamerata (Subbotina)

A, B - SEM images of isolated specimens; C - detail of surface of test B (scale bar $=25 \mu \mathrm{m}$ ); D, E - stereomicroscope photos of isolated specimens; $F-L-$ transmitted light photos of experimental thin-sections of $A$. pentacamerata; scale bars $=100 \mu \mathrm{m}$ 


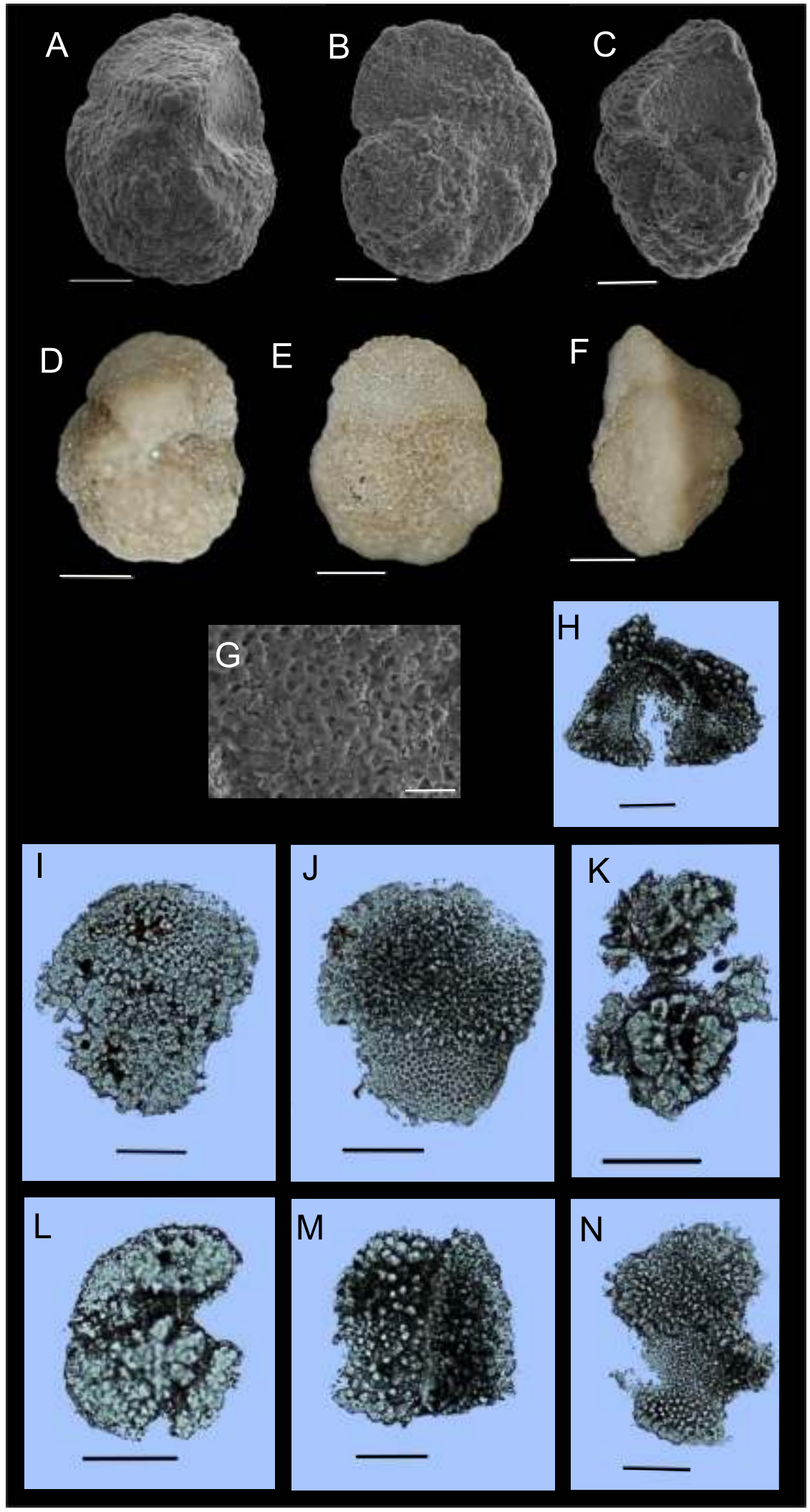

Fig. 10. Morozovella aragonensis (Nuttal)

A-C - SEM images of isolated specimens; $\mathbf{D}-\mathbf{F}$ - stereomicroscope photos of isolated specimens; $\mathbf{G}$ - detail of surface of test $\mathbf{C}$ (scale bar $=25 \mu \mathrm{m}$ ); $\mathbf{H}-\mathbf{N}-$ transmitted light photosof experimental thin-sections of $M$. aragonensis; scale bars $=100 \mu \mathrm{m}$ 


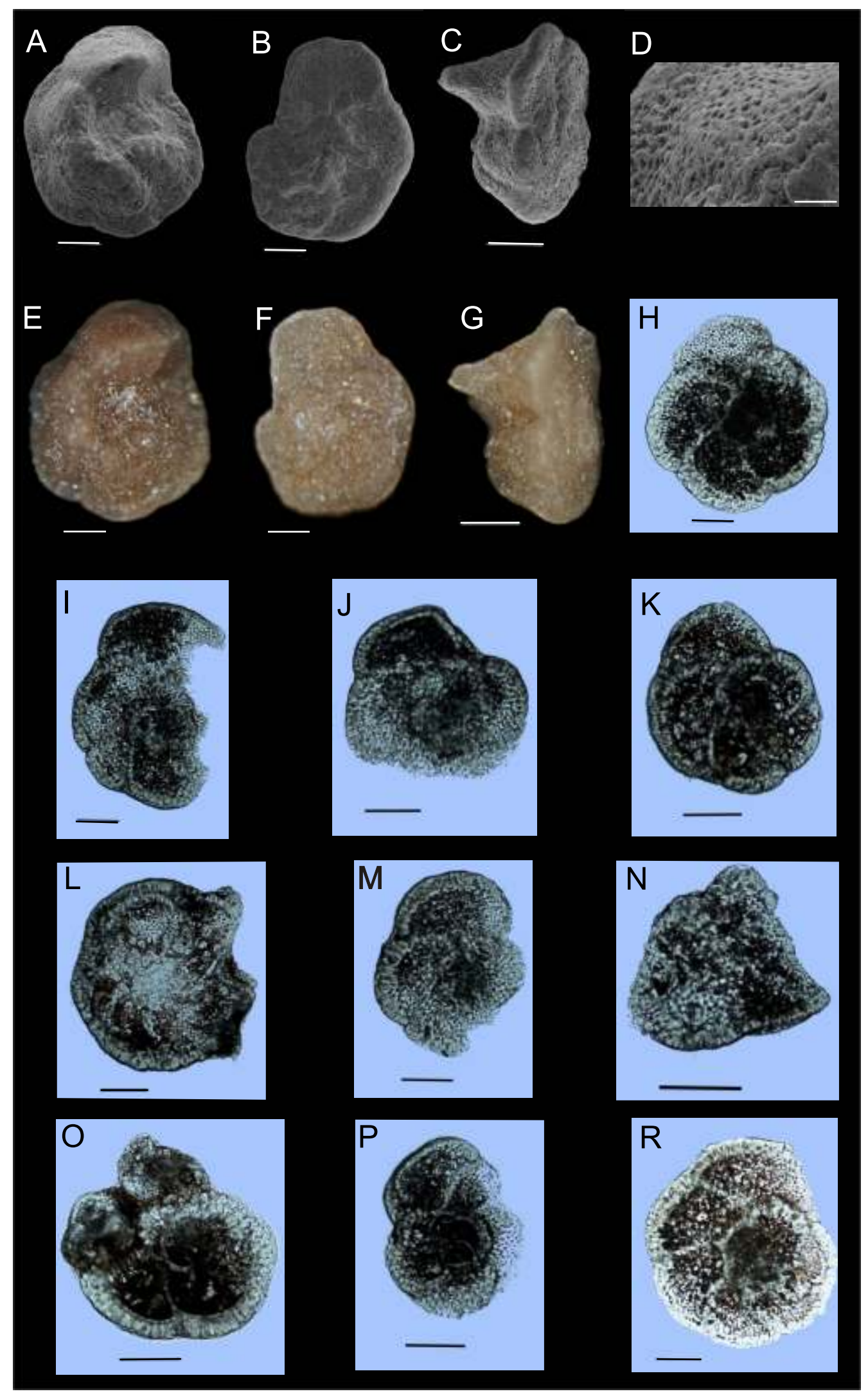

Fig. 11. Morozovella cf. caucasica (Glaessner)

A-C - SEM images of isolated specimens; D - detail of surface of test A (scale bar $=25 \mu \mathrm{m}$ ); E-G - stereomicroscope photos of isolated specimens; $\mathbf{H}-\mathbf{R}$ - transmitted light photos of experimental thin-sections of $M$. cf. caucasica; scale bars $=100 \mu \mathrm{m}$ 


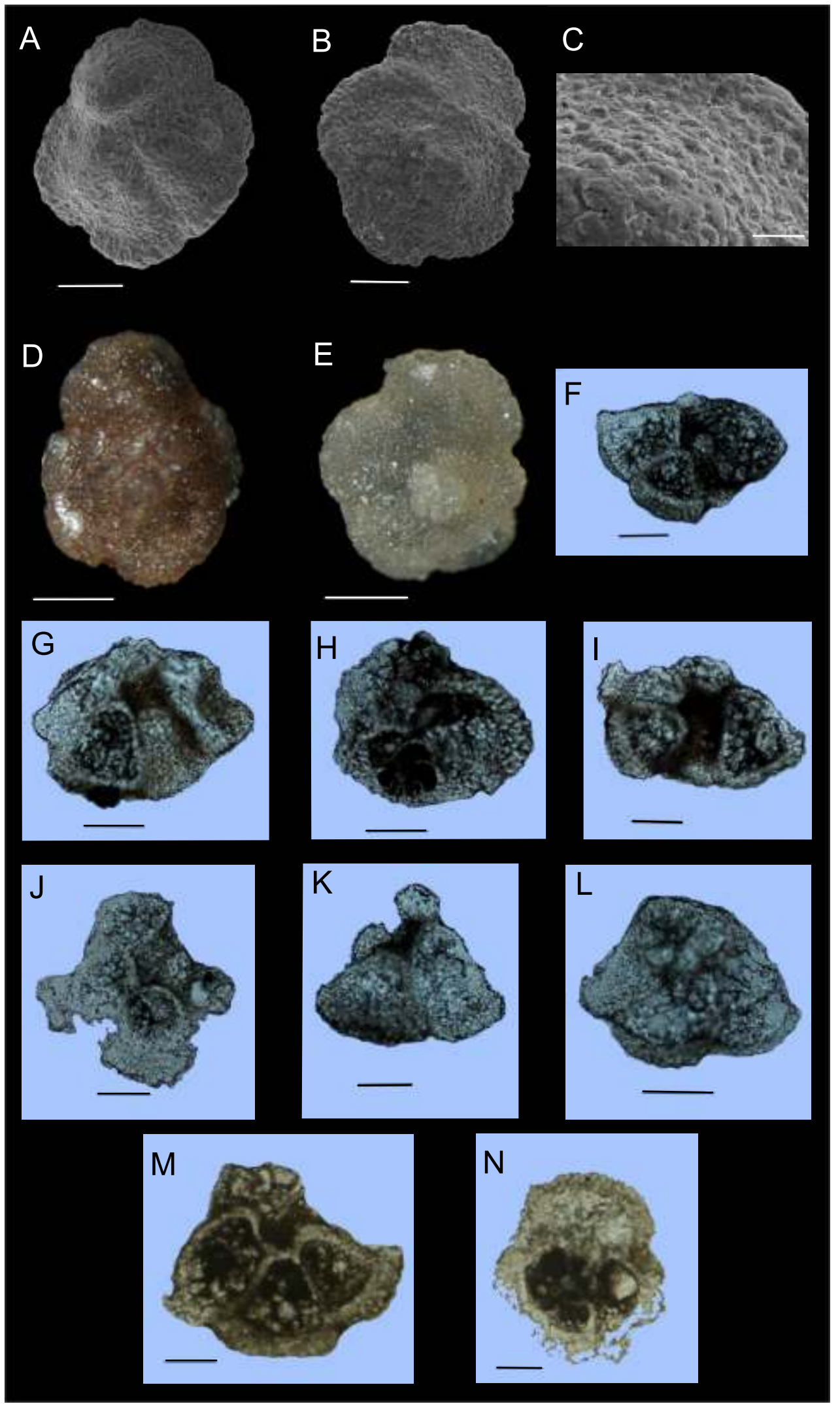

Fig. 12. Morozovella gracilis (Bolli)

A, B - SEM images of isolated specimens; C - detail of surface of test A (scale bar $=25 \mu \mathrm{m}$ ); $\mathbf{D}, \mathbf{E}-$ stereomicroscope photos of isolated specimens; F-L - transmitted light photos of experimental thin-sections of $M$. gracilis; $\mathbf{M}, \mathbf{N}$ - stereomicroscope photos of experimental thin-sections of $M$. gracilis; scale bars $=100 \mu \mathrm{m}$ 


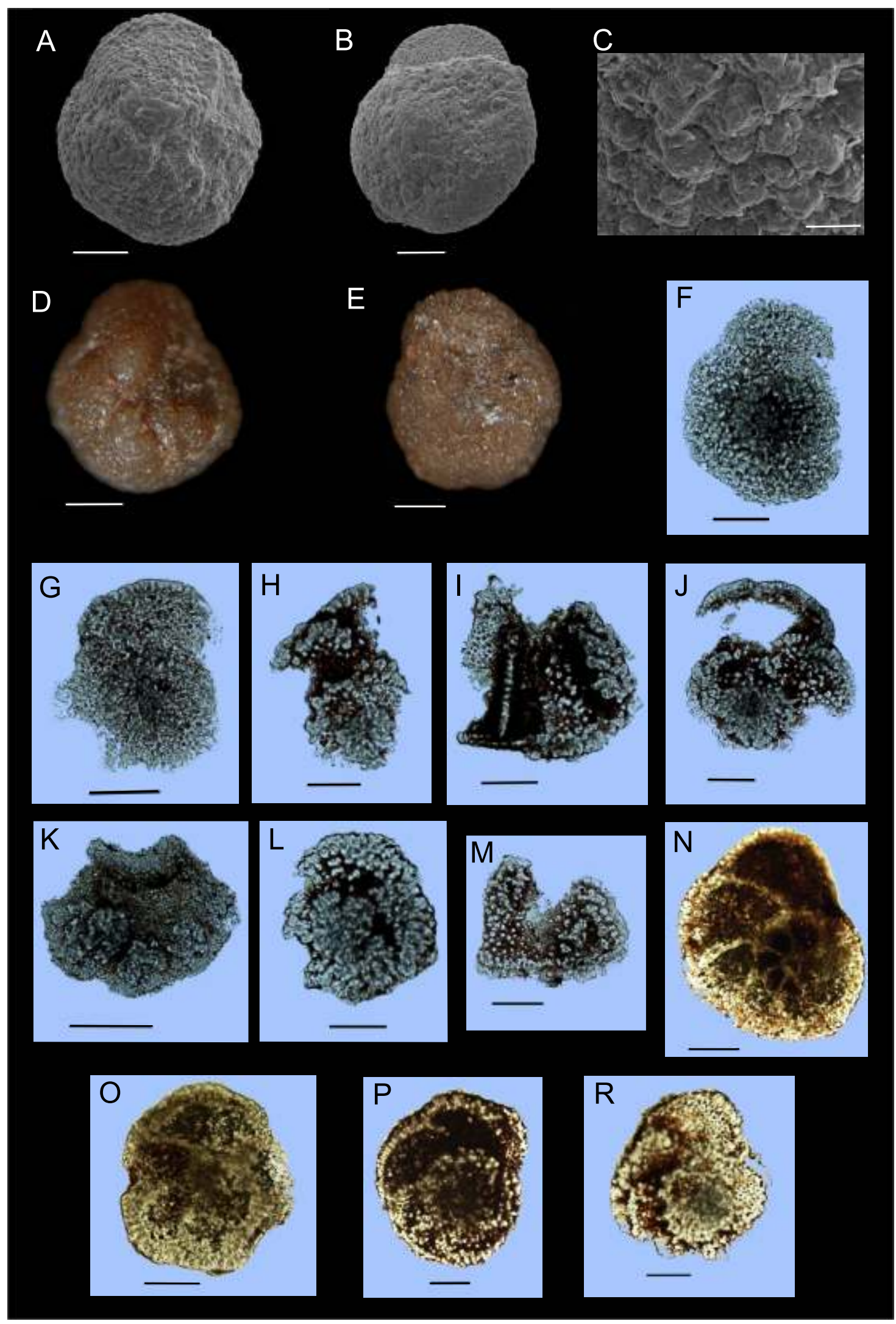

Fig. 13. Morozovella lensiformis (Subbotina)

A, B - SEM images of isolated specimens; $\mathbf{C}$ - detail of surface of test A (scale bar $=25 \mu \mathrm{m}$ ); D, E - stereomicroscope photos of isolated specimens; F-R - transmitted light photos of experimental thin-sections of $M$. lensiformis; scale bars $=100 \mu \mathrm{m}$ 
Stratigraphic range. - Middle Early Eocene (E4-E6 zones; Berggren and Pearson, 2005; Pearson et al., 2006); in the POC, reported from the Early Eocene (Olszewska et al., 1996).

Re m a rks. - In spite of diagenetic obliteration the characteristic muricate surface texture is visible both on isolated specimens (Fig. 13C) and in some sections (Fig. 13F, G). In Figure $13 F$ and $G$ transverse dorsal cuttings similar to those of $M$. aragonensis can be recognized. Figure $13 \mathrm{~N}$ and $\mathrm{P}$ shows transverse dorsal cuttings, and Figure 130 depicts a section transversal to coil axis through the central part of a test.

\section{Morozovella marginodentata (Subbotina, 1953)}

$$
\text { (Fig. 14) }
$$

Globorotalia marginodentata n. sp. - Subbotina (1953): 212, 213, pl. 17, fig. 14-16; pl. 18, figs. 1-3.

Morozovella marginodentata (Subbotina) - Olszewska et al. (1996): 120, pl. 37, figs. $1,2$.

S t r a t ig raphic rang e. - Latest Paleocene-Early Eocene (P5-E5 zones; Berggren and Pearson, 2005; Pearson et al., 2006); in the POC - oldest Early Eocene (Olszewska et al., 1996).

$\mathrm{R}$ e $\mathrm{m}$ a r k s. - The species with a very characteristic thick and broad peripheral muricocarina. Due to moderately convex spiral side, most of the cuts are oblique. The sections in Figure 14E, $G$ and $M$ display peripheral carina (keel). Figure $14 \mathrm{H}$ shows transverse umbilical cut. Species identification can be based on the section in Figure $14 \mathrm{H}$.

\section{Morozovella subbotinae (Morozova, 1939)}

$$
\text { (Fig. 15) }
$$

Globorotalia subbotinae n. sp. - Morozova (1939): 80, pl. 2, fig. 16, 17 (fide Ellis et Messina, Cat. of Foram.).

Morozovella subbotinae (Morozova) - Olszewska et al. (1996): 120, 121, pl. 37, figs. 11, 12.

S t r a tigraphic rang e. - Latest Paleocene-Early Eocene (P5-E5 zones; Berggren and Pearson, 2005; Pearson et al., 2006); in the POC - Early Eocene excluding its youngest part (Olszewska et al., 1996).

$\mathrm{R}$ e $\mathrm{m}$ a r k s. - Most of the experimental sections do not display diagnostic features of this species, however, the section in Figure 150 can be used for species identification. Wall surface texture is well-visible on isolated specimens (Fig. 15D, G).

\section{Muricoglobigerina senni (Beckmann, 1954)}

$$
\text { (Fig. 16) }
$$

Sphaeroidinella senni n. sp. - Beckmann (1954): 394, pl. 26, fig. 2 (fide Ellis et Messina, Cat. of. Foram.).

Muricoglobigerina senni (Beckmann) - Olszewska et al. (1996): 122 pl. 42, figs. 13, 14.

S t r a t i g r a p h i c r a n g e. - Late Early-Middle Eocene (E6-E13; Berggren and Pearson, 2005; Pearson et al., 2006); in the POC - late Middle Eocene (Olszewska et al., 1996).

R e $\mathrm{m}$ a r k s. - Recently, this species has been placed in the genera Muricoglobigerina (Olszewska et al., 1996), Subbotina (Pearson et al., 2006) and Globigerinatheka (BouDagher-Fadel, 2012). In this paper, we accept its genetic designation to Muricoglobigerina. In the adult stage, its wall is covered by a thick calcite crust, which is shown in Figure 16D, E. The sections in Figure 16F and K display a "sacculifer type" of test surface (Pearson et al., 2006). Species identification can be based on the sections in Figure16F, M and $\mathrm{O}$, showing the characteristic compact and globular morphology of its test.

\section{Subbotina corpulenta (Subbotina, 1953)}

(Fig. 17)

Globigerina corpulenta n. sp. - Subbotina (1953): 76, pl. 9, fig. 5. Subbotina corpulenta (Subbotina ) - Olsson et al. (2006): 129, 130, 133 , pl. 6.7 , figs. $1-14$.

Stratigraphic range. - Middle Eocene-Early Oligocene (E7-O1 zones; Berggren and Pearson, 2005; Pearson et al., 2006); in the POC - Late Eocene (Olszewska et al., 1996).

$\mathrm{R}$ e $\mathrm{m}$ a rk s. - The species is characterized by a lobulate test, usually with 4 globular chambers in ultimate whorl, and by the frequent presence of bulla-like chamber covering umbilical area. Due to a more or less spherical test, thin-sections randomly cut single chambers that are not diagnostic for taxonomic assignments. In Figure 17G, the section displays a characteristic cancelate (honeycomb-like) surface texture.

\section{Subbotina eocaena (Gümbel, 1868)}

(Fig. 18)

Globigerina eocaena n. sp. - Gümbel (1868): 662, pl. 2, fig. 109a, b (fide Ellis et Messina, Cat. of. Foram.).

Subbotina eocaena (Gümbel) - Olsson et al. (2006): 134, 137, 138, pl. 6.9 , figs. $1-16$.

Stratigraphic range. - Early Eocene-earliest Oligocene (?E6-O1 zones; Berggren and Pearson, 2005; Pearson et al., 2006); in the POC - latest Early-Late Eocene (Olszewska et al., 1996).

R e m a rks. - Randomly oriented sections are usually transversal to the whorl axis. In Figure $18 \mathrm{H}$ and I, "rubber/sacculifer"-type wall texture (Pearson et al., 2006) of the surface is visible. In Figure $18 \mathrm{~L}$ and $\mathrm{M}$, the sections display a general shape of a test. Species identification can be based on the sections in Figure 18G, L, M.

\section{Subbotina hagni (Gohrbandt, 1967)}

(Fig. 19)

Globigerina hagni n. sp. - Gohrbandt (1967): 325, pl. 1, fig. 1-3.

Subbotina hagni (Gohrbandt) - Olsson et al. (2006): 142, 145, pl. 6.11, figs. $1-17$.

Stratigraphic range. - Middle-Late Eocene (E7-E16 zones; Berggren and Pearson, 2005; Pearson et al., 2006); in the POC - Middle-Late Eocene (Olszewska et al., 1996).

R e m a rk s. - S. hagni is similar to $S$. eocaena, and its sections display some similarities. However, they are mainly transversal, usually cutting only some of the chambers. Its sections reveal "sacculifer" - type wall texture.

\section{Subbotina linaperta (Finlay, 1939)} (Fig. 20)

Globigerina linaperta n. sp. - Finlay (1939): 126, pl. 13, fig. 56 (fide Ellis et Messina, Cat. of. Foram.).

Subbotina linaperta (Finlay) - Olsson et al. (2006): 149, 150, 153, 154, pl. 6.14 , figs. $1-16$.

St r a tigraphic rang e. - Late Early-Late Eocene (E5-E16 zones; Berggren and Pearson, 2005; Pearson et al., 2006); in the POC - Paleocene-Eocene (Olszewska et al., 1996).

R e m a r k s. - Its thin-sections (Fig. 20F-O) display "sacculifer"-type wall texture (Pearson et al., 2006). Most of the cross-sections reveal characteristic features of this species. The sections display various directions of cuttings, both axial (Fig. 20J) and transversal (Fig. 200), and they show a general 


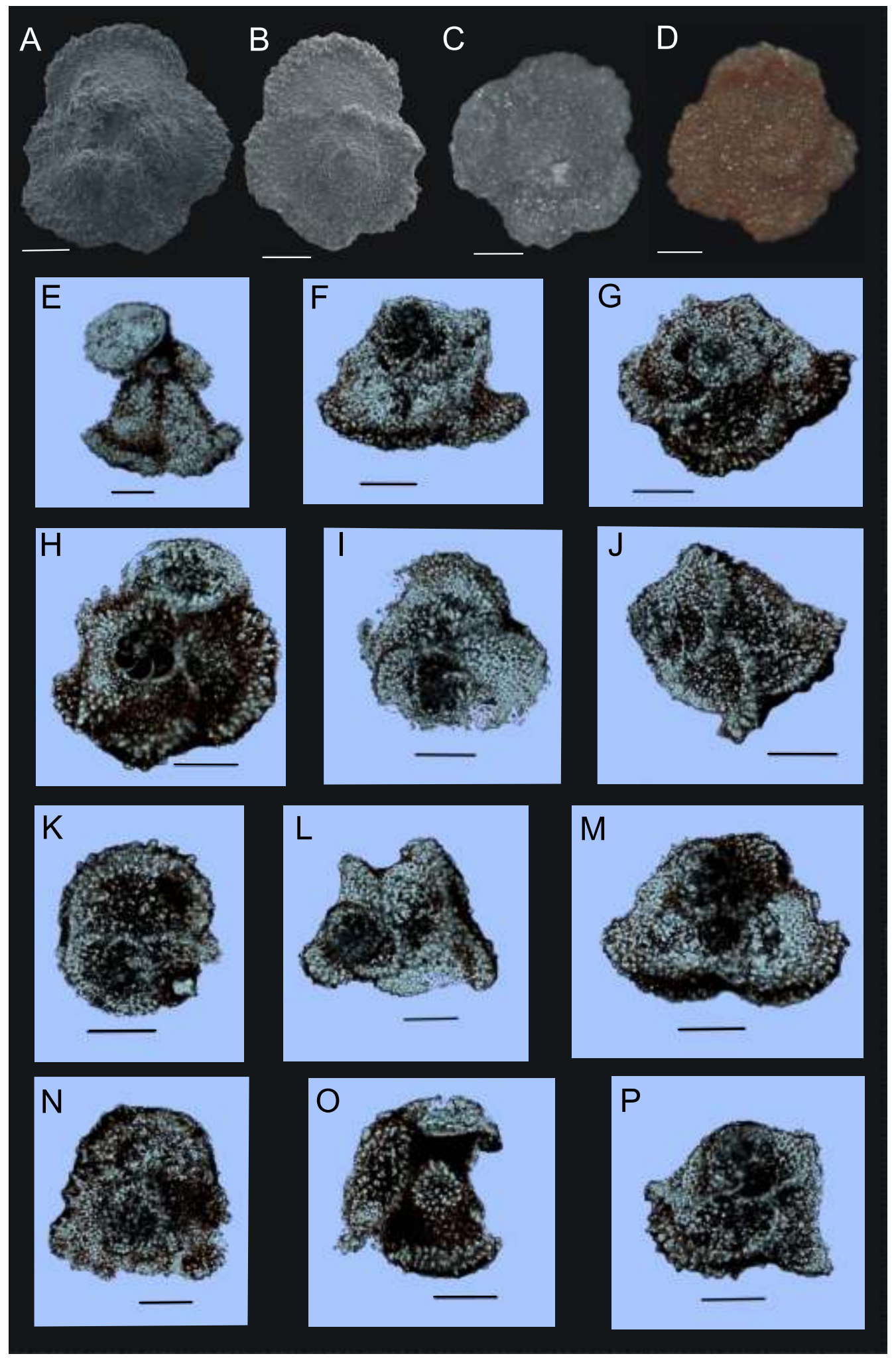

Fig. 14. Morozovella marginodentata (Subbotina)

A, B - SEM images of isolated specimens; C, D - stereomicroscope photos of isolated specimens; E-P - transmitted light photos of experimental thin-sections of $M$. marginodentata; scale bars $=100 \mu \mathrm{m}$ 


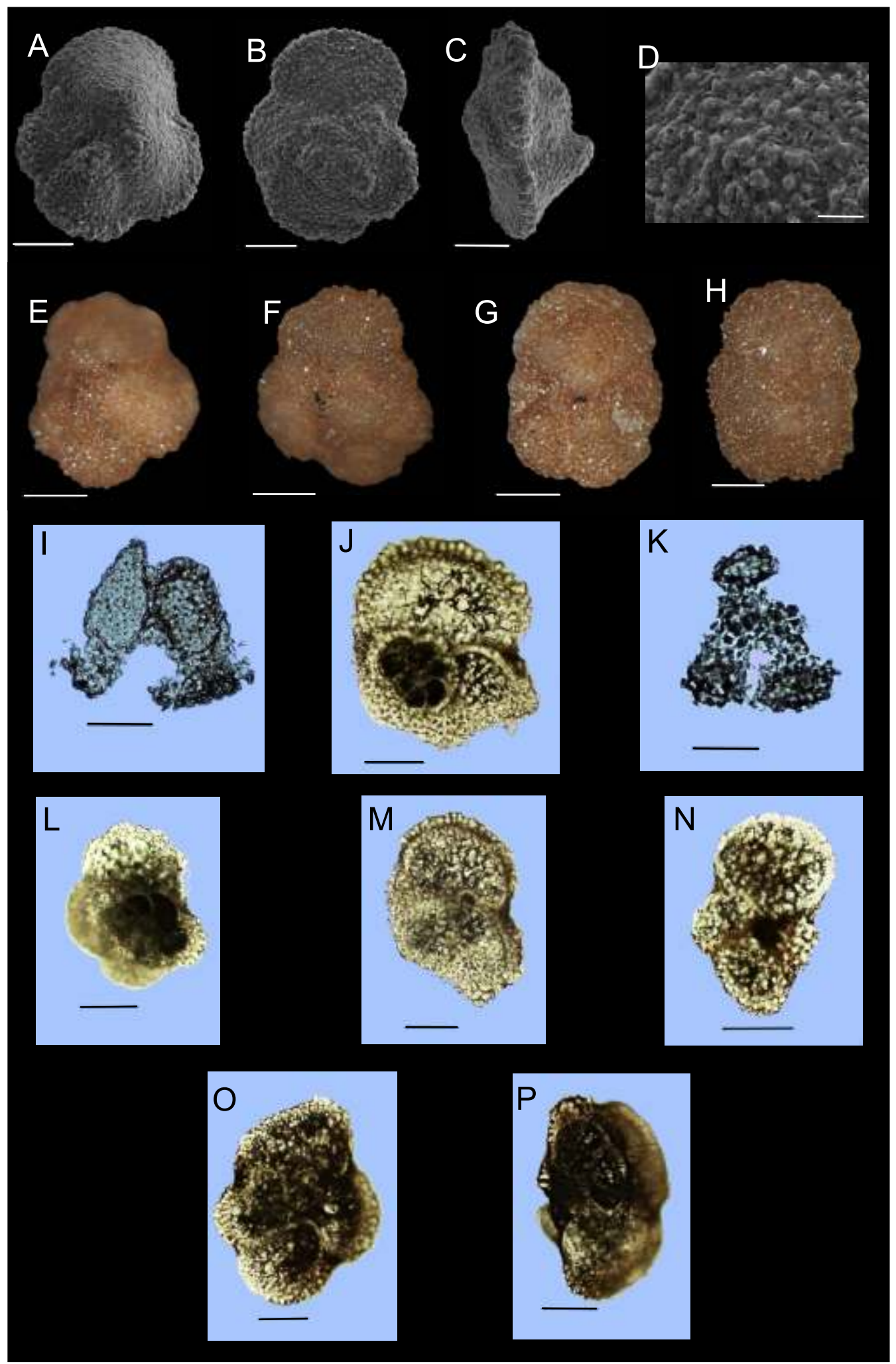

Fig. 15. Morozovella subbotinae (Morozova)

A-C - SEM images of isolated specimens; $\mathbf{D}$ - detail of surface of test A (scale bar $=25 \mu \mathrm{m}$ ); $\mathbf{E}-\mathbf{H}-$ stereomicroscope photos of isolated specimens; I-P - transmitted light photos of experimental thin-sections of $M$. subbotinae; scale bars $=100 \mu \mathrm{m}$ 

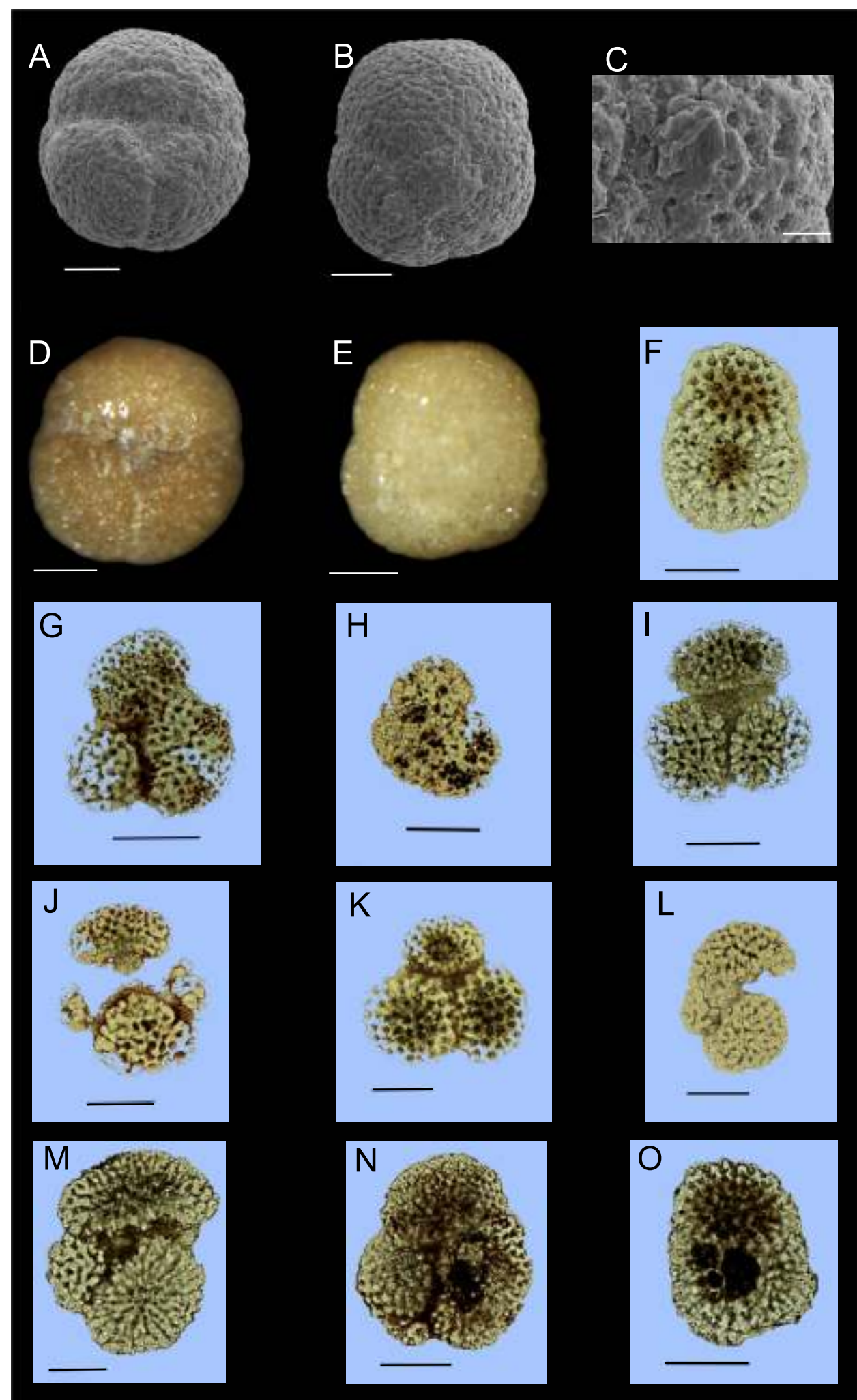

Fig. 16. Muricoglobigerina senni (Beckmann)

A, B - SEM images of isolated specimens; C - detail of surface of test B (scale bar $=25 \mu \mathrm{m}$ ); D, E - stereomicroscope photos of isolated specimens; F-O - transmitted light photos of experimental thin-sections of M. senni; scale bars $=100 \mu \mathrm{m}$ 


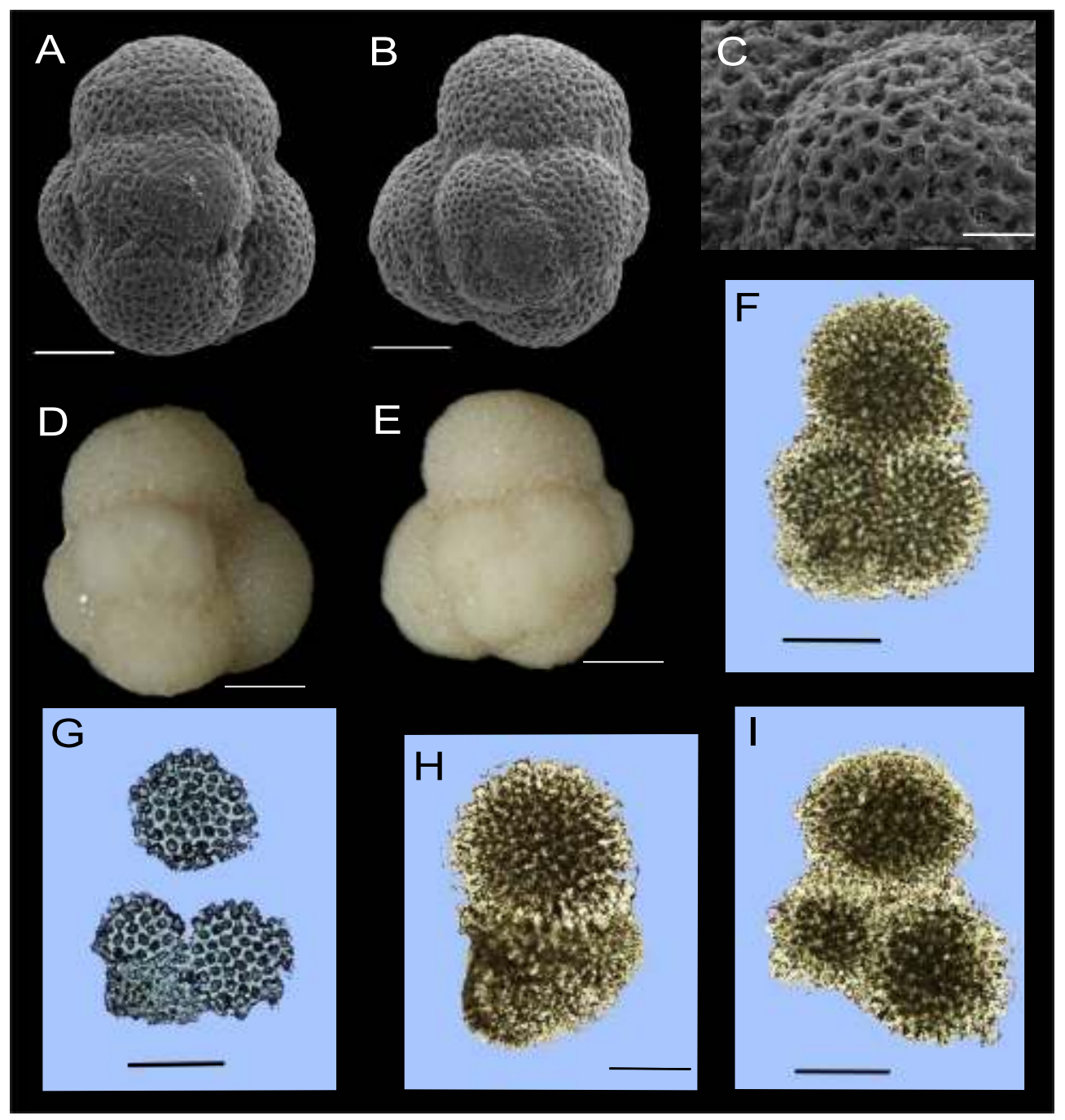

Fig. 17. Subbotina corpulenta (Subbotina)

A, B - SEM images of isolated specimens; D, E - stereomicroscope photos of isolated specimens; F-I - transmitted light photos of experimental thin-sections of $S$. corpulenta; scale bars $=100 \mu \mathrm{m}$

character of the species test. Species identification can be based on the sections in Figure 20F, G.

\section{Subbotina cf. roesnaesensis Olsson and Berggren, 2006}

$$
\text { (Fig. 21) }
$$

Subbotina roesnaesensis n. sp. - Olsson et al. (2006): 157, pl. 6.16, fig. 1-15.

Stratigraphic range. - Latest Paleocene-early Middle Eocene (P5-E10 zones; Berggren and Pearson, 2005; Pearson et al., 2006).

$\mathrm{R}$ e $\mathrm{m}$ a r k s. - Lack of distinct wall texture in comparison with the other species of Subbotina. Cuttings are usually random with some inclination to be transversal.

In Figure 21M the section shows a distinct aperture. Experimental cuttings of this species display similarities to other species of Subbotina.

Subbotina triangularis (White, 1928) (Fig. 22)
Globigerina triangularis n. sp. - White (1928): 195, pl. 28, fig. 1 (fide Ellis et Messina, Cat. of Foram.).

Subbotina triangularis (White) - Olsson et al. (1999): 30, 31, pl. 26, figs. $1-13$.

Stratigraphic rang e. - Late Paleocene (Olsson et al., 1999).

$\mathrm{R}$ e $\mathrm{m}$ a rks. - In the thin-sections the wall texture shows some similarities to $S$. roesnaensis. The cross-sections are randomly oriented without any preferential position of specimens, resulting from its overall morphology. Species identification can be based on the sections in Figure 22E, G and K.

\section{Parasubbotina inaequispira (Subbotina, 1953)}

$$
\text { (Fig. 23) }
$$

Globigerina inaequispira n. sp. - Subbotina (1953): 69, pl. 6, fig. 1. Parasubbotina inaequispira (Subbotina) - Olszewska et al. (1996): 141, 142, pl. 15, fig. 1.

Stratigraphic range. - Early Eocene-earliest Middle Eocene (E1-E8 zones; Berggren and Pearson, 2005; 


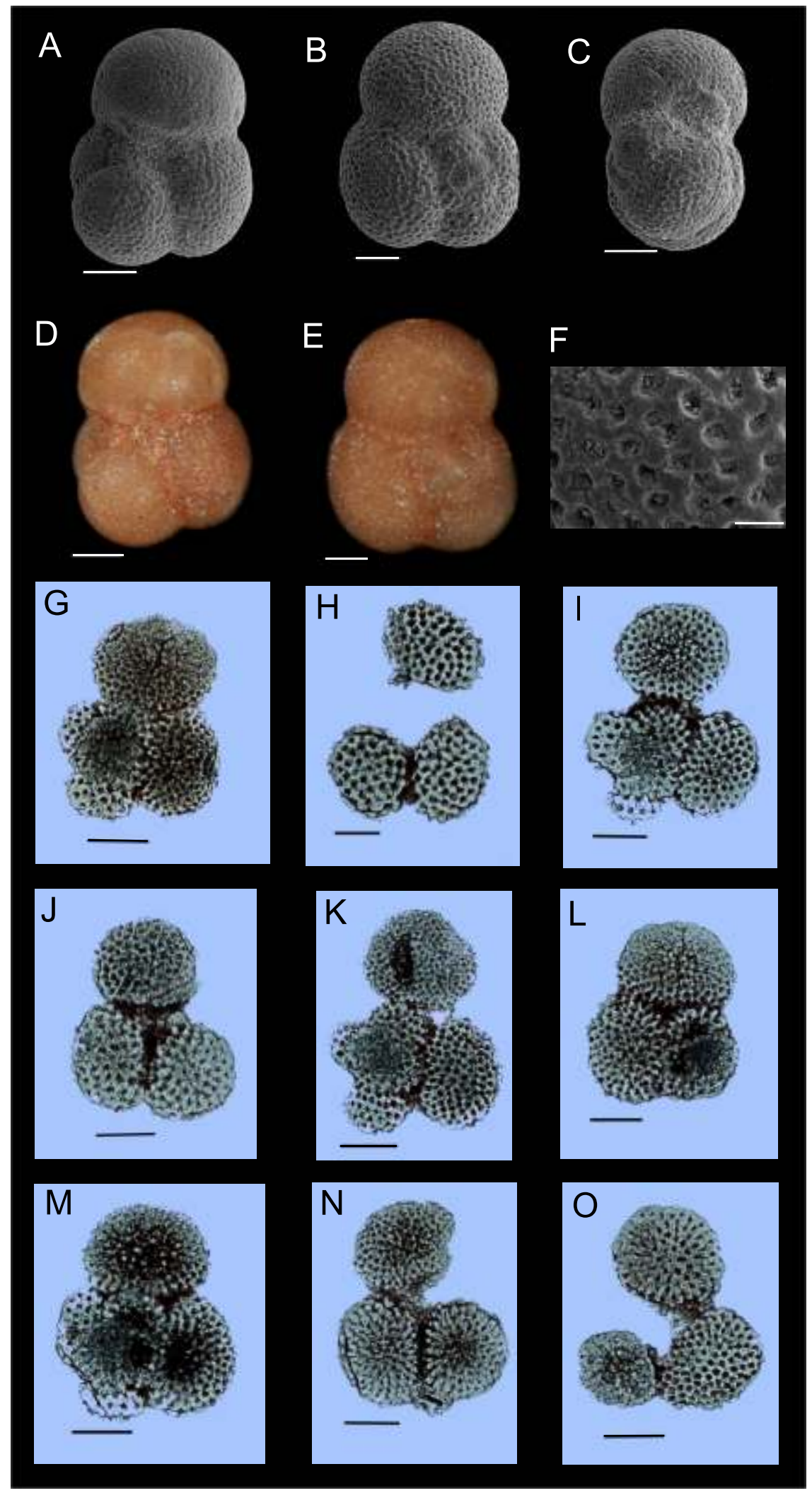

Fig. 18. Subbotina eocaena (Gümbel)

A-C - SEM images of isolated specimens; $\mathbf{D}, \mathbf{E}$ - stereomicroscope photos of isolated specimens; $\mathbf{F}$ - detail of surface of test B (scale bar $=25 \mu \mathrm{m}$ ); $\mathbf{G}-\mathbf{O}-$ transmitted light photos of experimental thin-sections of $S$. eocaena; scale bars $=100 \mu \mathrm{m}$ 


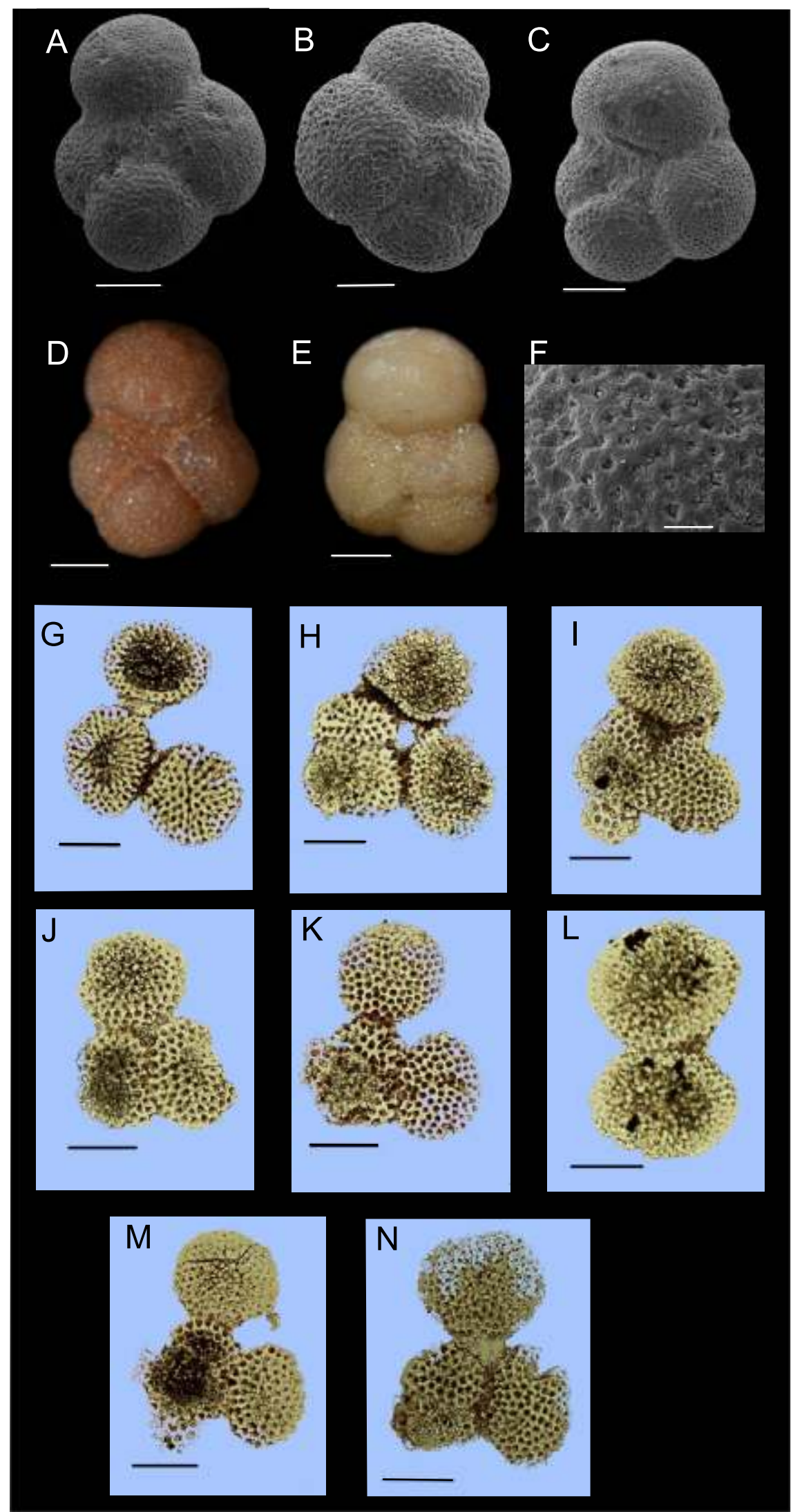

Fig. 19. Subbotina hagni (Gohrbandt)

A-C - SEM images of isolated specimens; D, E - stereomicroscope photos of isolated specimens; $\mathbf{F}$ - detail of surface of test B (scale bar $=25 \mu \mathrm{m}$ ); G-N - transmitted light photos of experimental thin-sections of $S$. hagni; scale bars $=100 \mu \mathrm{m}$ 

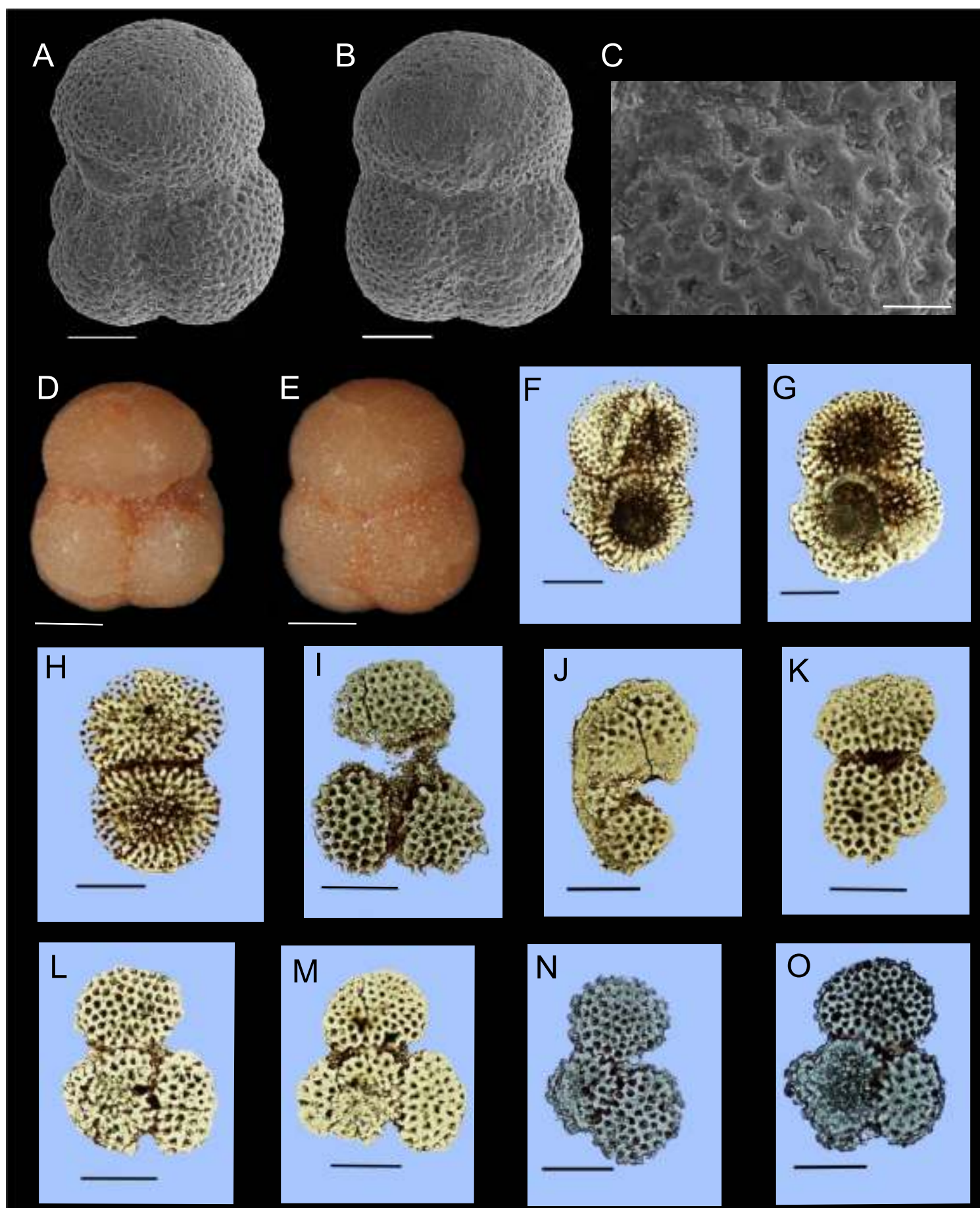

Fig. 20. Subbotina linaperta (Finlay)

A, B - SEM images of isolated specimens; C - detail of surface of test A (scale bar $=25 \mu \mathrm{m}$ ); D, E - stereomicroscope photos of isolated specimens; F-O - transmitted light photos of experimental thin-sections of $S$. linaperta; scale bars $=100 \mu \mathrm{m}$ 


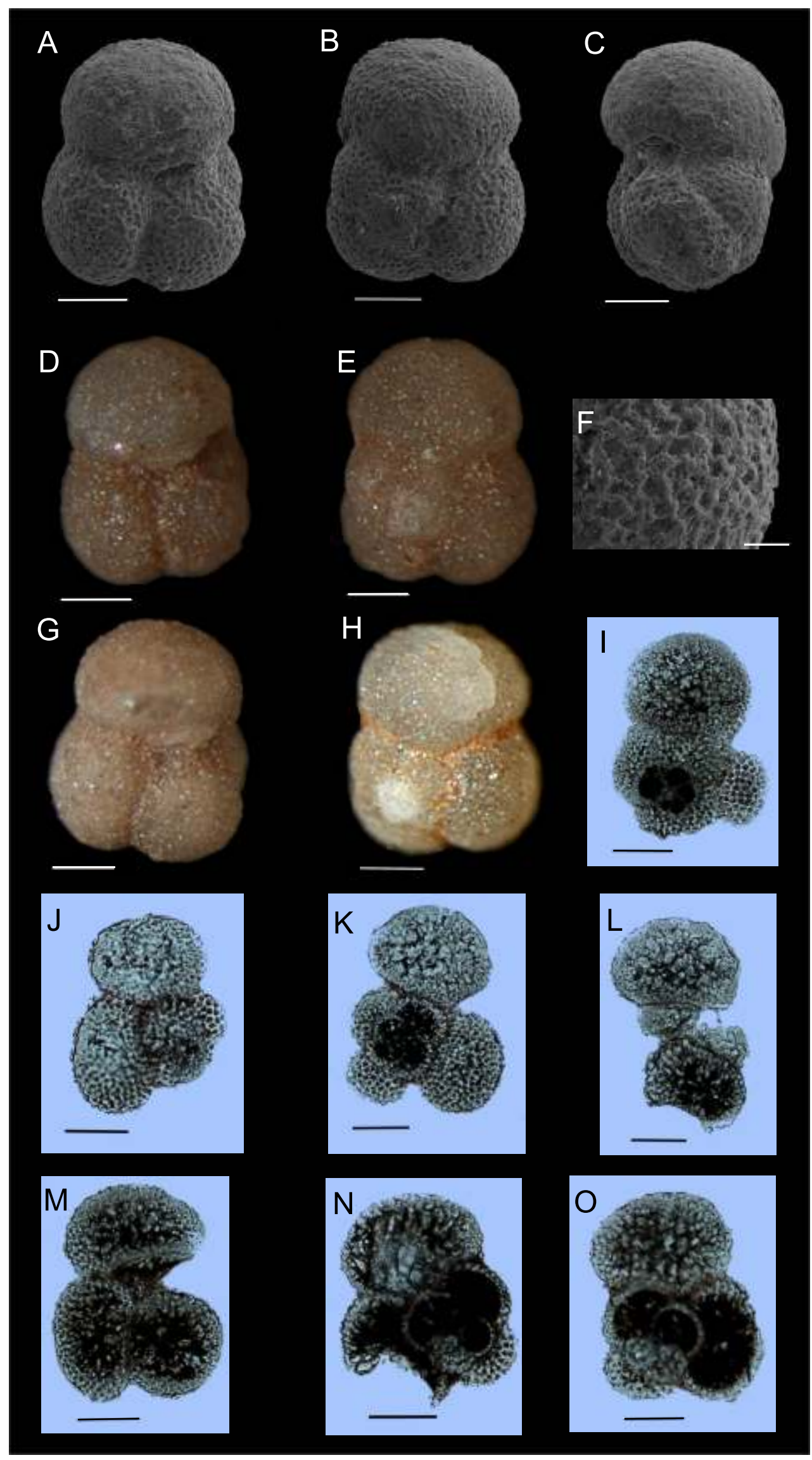

Fig. 21. Subbotina cf. roesnaesensis (Olsson and Berggren)

A-C - SEM images of isolated specimens; D-E, G, H - stereomicroscope photos of isolated specimens; $\mathbf{F}$ - detail of surface of test $B($ scale bar $=25 \mu \mathrm{m}) ; \mathbf{I}-\mathbf{O}-$ transmitted light photos of experimental thin-sections of $S$. cf. roesnaesensis; scale bars $=100 \mu \mathrm{m}$ 

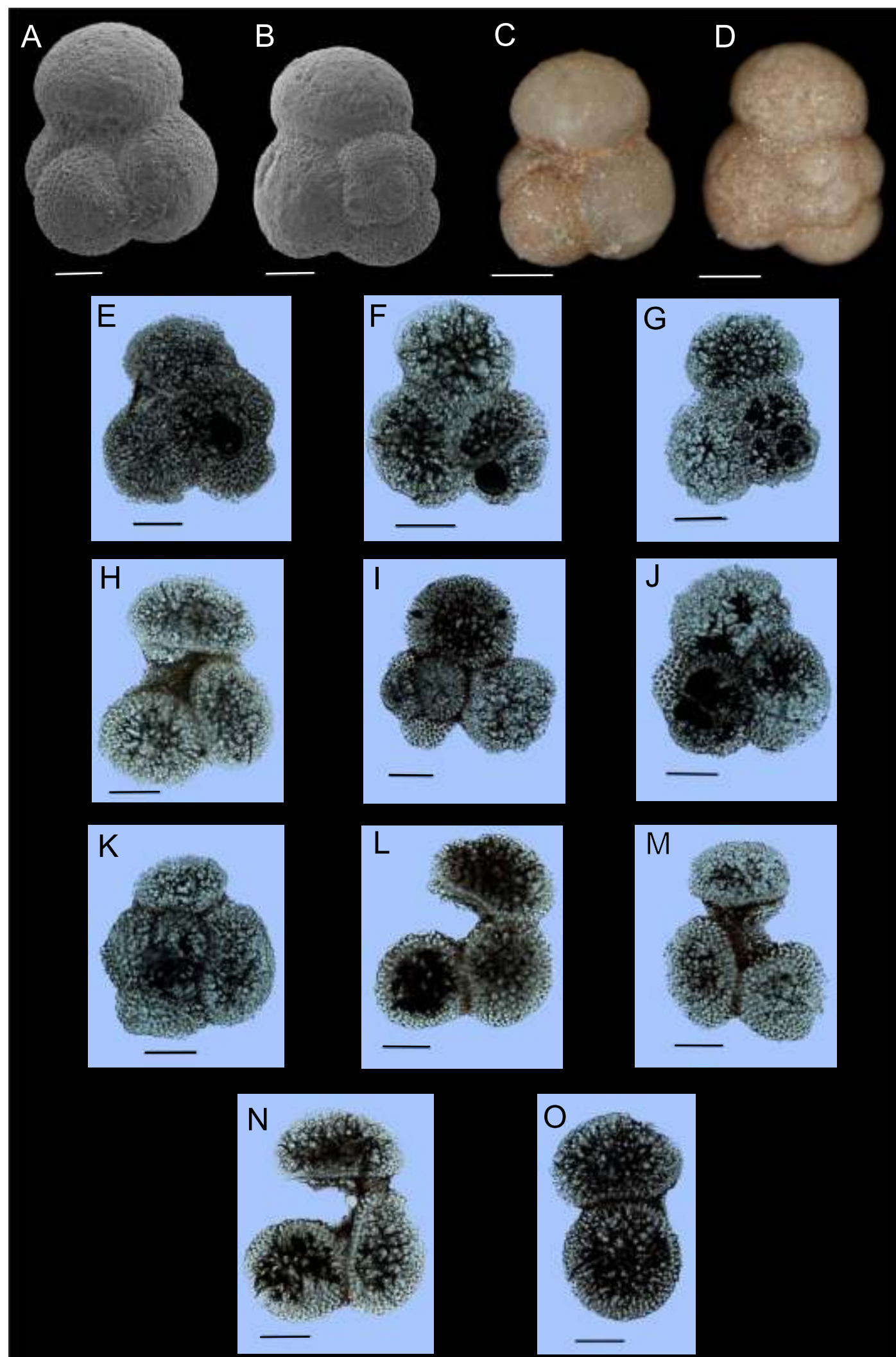

Fig. 22. Subbotina triangularis (White)

A, B - SEM images of isolated specimens; C, D - stereomicroscope photos of isolated specimens; E-O - transmitted light photos of experimental thin-sections of $S$. triangularis; scale bars $=100 \mu \mathrm{m}$ 


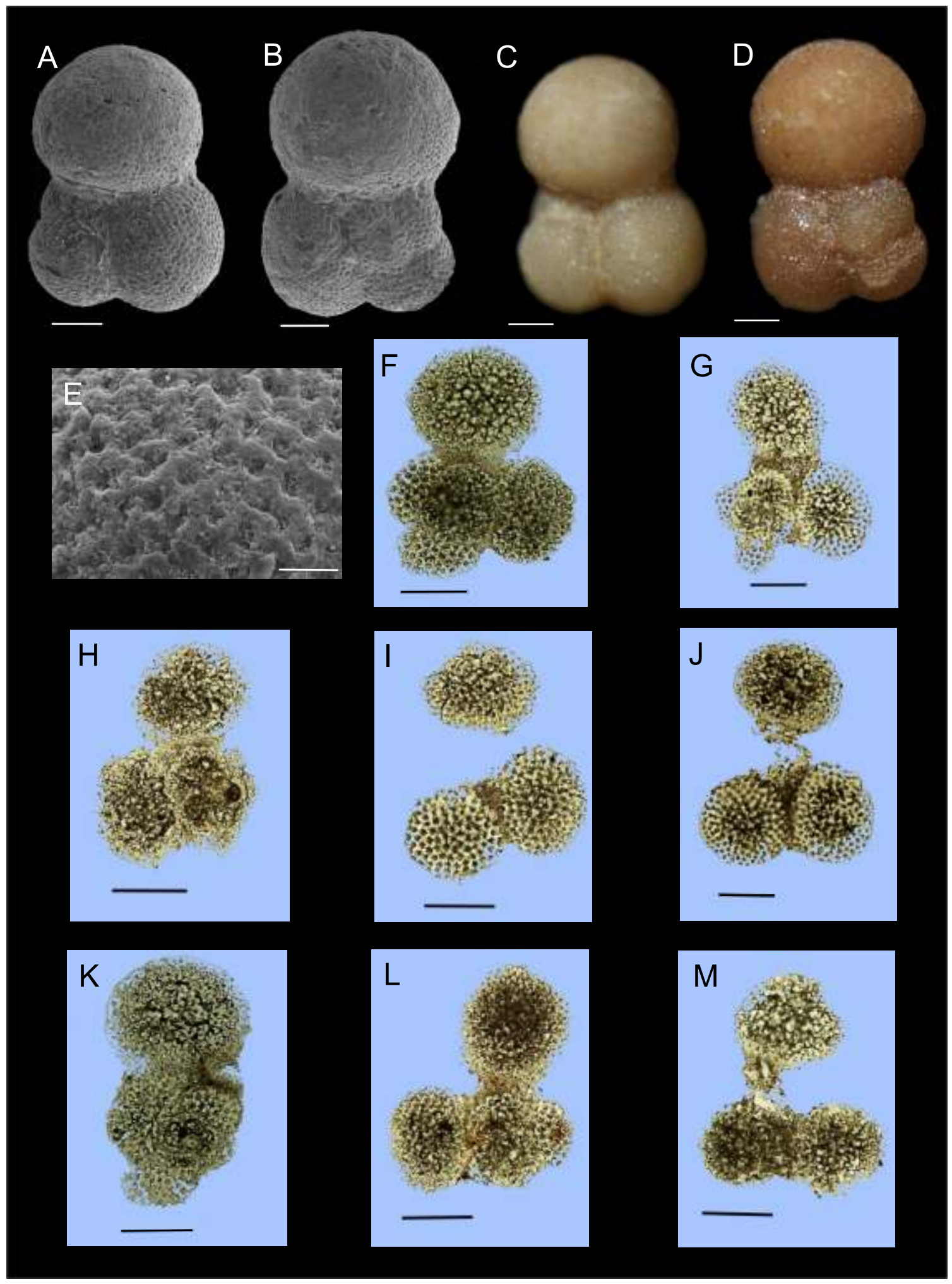

Fig. 23. Parasubbotina inaequispira (Subbotina)

A, B - SEM images of isolated specimens; $\mathbf{E}$ - detail of surface of test A (scale bar $=25 \mu \mathrm{m}$ );

C, D - stereomicroscope photos of isolated specimens; $\mathbf{F}-\mathbf{M}$ - transmitted light photos of experimental thin-sections of $P$. inaequispira; scale bars $=100 \mu \mathrm{m}$ 
Pearson et al., 2006); in the POC - youngest Late Paleocene-Early Eocene (Olszewska et al., 1996).

Re $\mathrm{m}$ a rks. - The wall texture shows some similarities to a "sacculifer"-type, commonly occurring in the genus Subbotina. The cuttings are random due to globular chambers and do not display the characteristic test morphology, however, showing some overall similarities to some species of Subbotina (Fig. 23F). Species identification can be based on the section in Figure 23F.

\section{SUMMARY}

The original method applied for thin-section on isolated specimens of planktic foraminifera, using epoxy resin (Araldyte 1000-Struers), appeared to be sufficiently effective in the course of the first experiment of this kind.

The quality of experimental thin-sections in respect to diagnostic features of a particular species much depends on the general test morphology, resulting in the random but preferential position of specimens immersed and then hardened in epoxy resin.

Random cuttings of various taxa, exhibiting morphological resemblance, result in similar figures that show no morphological criteria necessary for the determination to a specific taxonomic level. In our material, this refers particularly to the group of Subbotina.

Based on the experimentally obtained cross-sections we can conclude that taxonomic identification, at least to the generic level, is possible.

Diagnostically best sections have been obtained for the biserial specimens of elongated, flattened "wedge-shape" tests of Chiloguembelina, which have a natural tendency to axial-sagittal orientation of plane cuts.
Oblique thin-sections of trochospiral tests with globigeriniform coiling, which are generally biconvex and lobulate (round-shaped group), such as Subbotina and Parasubbotina, usually cut a smaller number of chambers, but display globular shapes of chambers and cancelate surface texture. Transversal sections, more centrally situated, show a characteristic lobulate outline of their tests.

Trochospiral tests with a truncated cone shape and flattened dorsal side reveal natural tendency to get into position resulting in sections more or less transversal to the axis of coiling. Their truncated cone shape is usually preserved in oblique sections; however, sections of tests representing such morphology are of variable quality. Peripheral margins with distinct muricocarina, which is characteristic of majority of species within the Morozovella genus, are present in most of their sections. The outlines of tests of both types of acarinids, with angular and rounded chambers, are displayed in their transverse dorsal sections.

SEM images of identified species show considerable diagenetic obliterations that, in most cases, blur the primary and characteristic texture of test surfaces while in some thin-sections these textural features are better preserved (e.g., Subbotina hagni).

The sections from our experiment reveal that their diagnostic quality could have been higher if the specimens of particular species used in a single slide had been of similar sizes. In case of continuation of such experiment, mechanical grounding of slides should also be tested.

Acknowledgements. Our thanks go to Dr Eng. B. Budzyń for his advice concerning material used in our experimental slides. We are very grateful to our reviewers Prof. V. Ćosović and Dr J. Kowal for their constructive suggestions and encouraging comments.

\section{REFERENCES}

Berggren, W.A., Pearson, P.N., 2005. A revised tropical to subtropical Paleogene planktonic foraminiferal zonation. Journal of Foraminiferal Research, 35: 279-298.

Berggren, W.A., Pearson, P.N., 2006. Taxonomy, biostratigraphy, and phylogeny of Eocene Morozovella. Cushman Foundation Special Publication, 41: 343-375.

Berggren, W.A., Hemleben, Ch., Norris, R.D., Olsson, R.K., 1999. Family Truncorotaloididae Loeblich and Tappan, 1961. Smithsonian Contributions to Paleobiology, 85: 45-77.

Berggren, W.A., Pearson, P.N., Huber, B.T., Wade, B.S., 2006. Taxonomy, biostratigraphy, and phylogeny of Eocene Acarinina. Cushman Foundation Special Publication, 41: 257-326.

Bolli, H.M., 1957. Planktonic foraminifera from the Eocene Navet and San Fernando formations of Trinidad, B.W.I. U.S. National Museum Bulletin, 215: 155-172.

BouDagher-Fadel, M.K., 2012. Biostratigraphic and Geological Significance of Planktonic Foraminifera. Elsevier.

Burtan, J., Sokołowski, S., 1956. Nowe badania nad stosunkiem regionu magurskiego do krośnieńskiego w Beskidach Zachodnich (in Polish). Przegląd Geologiczny, 4: 457-458.

Cushman, J.A., Ponton, G.M., 1932. An Eocene foraminiferal fauna of Wilcox age from Alabama. Contributions from the Cushman Laboratory for Foraminiferal Research, 8: 51-72.
Cushman, J.A., Renz, H.H., 1942. Eocene, Midway, Foraminifera from Soldado Rock, Trinidad. Contributions from the Cushman Laboratory for Foraminiferal Research, 18: 1-20.

D'Hondt, S., Huber, B.T., 1999. Family Chiloguembelinidae Reiss, 1963. Smithsonian Contributions to Paleobiology, 85: 88-93.

Ellis, B., Messina, A., 1941-2000. Catalogue of Foraminifera and Supplements. The American Museum of Natural History Special Publication, New York.

Flügel, E., 2004. Microfacies of Carbonate Rocks. Analysis, Interpretation and Application. Springer, Berlin.

Gohrbandt, K.H.A., 1967. Some new planktonic foraminiferal species from the Austrian Eocene. Micropaleontology, 13: 319-326.

Huber, B.T., Olsson, R.K., Pearson, P.N., 2006. Taxonomy, biostratigraphy, and phylogeny of Eocene microperforate planktonic foraminifera (Jenkinsina, Cassigerinelloita, Chiloguembelina, Streptochilus, Zeauvigerina, Tenuitella, and Cassigerinella) and Problematica (Dipsidripella). Cushman Foundation Special Publication, 41: 461-507.

Ksia kiewicz, M., 1972. Budowa geologiczna Polski. Tektonika. Karpaty (in Polish). Wyd. Geol., Warszawa.

Lexa, J., Bezák, V., Elečko, M., Mello, J., Polák, M., Potfaj, M., Vozár, J. eds., 2000. Geological Map of Western Carpathians and Adjacent Areas, 1:500,000. Ministry of Environment of the Slovak Republic, Geological Survey of Slovak Republic, Bratislava. 
Malata, E., 2013. Zespoły małych otwornic jako wskaźnik poło enia obszaru sedymentacji utworów łuski przedmagurskiej w basenie Karpat zewnętrznych (in Polish). In: V Polska Konferencja Sedymentologiczna POKOS 5’2013. Głębokomorska sedymentacja fliszowa - sedymentologiczne aspekty historii basenów karpackich (eds. M. Krobicki and A. Feldman-Olszewska). 16-19.05.2013, ywiec: 198-200. Państwowy Instytut Geologiczny - PIB, Warszawa.

Malata, E., Malata, T., Oszczypko, N., 1996. Litho- and biostratigraphy of the Magura Nappe in the eastern part of the Beskid Wyspowy Range (Polish Western Carpathians). Annales Societatis Geologorum Poloniae, 66: 269-284.

Olsson, R.K., Hemleben, Ch., Liu, C., Berggren, W.A., Norris, R.D., 1999. Family Globigerinidae Carpenter, Parker and Jones, 1862. Smithsonian Contributions to Paleobiology, 85: 19-34.

Olsson, R.K., Hemleben, C., Huber, B.T., Berggren, W.A., 2006. Taxonomy, biostratigraphy, and phylogeny of Eocene Globigerina, Globoturborotalita, Subbotina, and Turborotalita. Cushman Foundation Special Publication, 41: 111-168.

Olszewska, B., Odrzywolska-Bieńkowa, E., Giel, M.D. Po aryska, K., Szczechura, J., 1996. Fauna - Bezkręgowce;
Rząd Foraminiferida Eichwald, 1830 (in Polish). In: Atlas skamieniałości przewodnich i charakterystycznych, $3 \mathrm{cz}$. 3a, Kenozoik, Trzeciorzęd, Paleogen (eds. L. Malinowska and M. Piwocki): 45-216. Polska Agencja Ekologiczna, Warszawa.

Pearson, P.N., Olsson, R.K., Huber, B.T., Hemleben, C., Berggren, W.A., Coxall, H.K., 2006. Overview of Eocene planktonic foraminiferal taxonomy, paleoecology, phylogeny and biostratigraphy. Cushman Foundation Special Publication, 41: 11-28.

Postuma, J., 1971. Manual of Planktonic Foraminifera. Elsevier.

Premoli Silva, J., Rettori, R., Verga, D., 2003. Practical Manual of Paleocene and Eocene Planktonic Foraminifera. Dipartamento di Scienze della Terra, Perugia (Italy).

Subbotina, N.N., 1953. Fossil foraminifera of the U.S.S.R., Globigerinidae, Hantkeninidae and Globorotalidae (in Russian). Trudy Vsesoyznogo Neftyanogo Nauchno-Issledovatel'skogo Geologo-Razvedochnogo Instituta (VNIGRI).

elaźniewicz, A., Aleksandrowski, P., Buła, Z., Karnkowski, P.H., Konon, A., Oszczypko, N., Ślączka, A., aba, J., ytko, K., 2011. Regionalizacja Tektoniczna Polski (in Polish). Komitet Nauk Geologicznych PAN, Wrocław. 